\title{
Muuttoliikkeestä ja sen syistä eräissä Kuopion läänin kunnissa vuosina 1921-1944
}

\author{
Kirjoittanut Reino Lento.
}

Tutkimuksen tarkoitus.

Viime vuosina on maassamme kiinnitetty yhä kasvavaa huomiota siihen muuttoliikkeeseen, joka suuntautuu varsinaiselta maaseudulta asutuskeskuksiin ja maataloudesta muihin elinkeinoihin. Tämän ns, »maaltapaon» tai »maataloudesta paon» syitä on pohdittu vilkkaasti, samoin myös sen seurauksia ja mahdollisia ehkäisykeinoja. Asian herättämä kiinnostus onkin hyvin ymmärrettävissä, kun ottaa huomioon sen suuren merkityksen, mikä muuttoliikkeellä on maan taloudellisille, sosiaalisille ja väestöoloille.

Kysymyksen väestöpoliittinen puoli lähinnä sai Väestöliitonkin omistamaan huomiota tälle ilmiölle. Koska väestön jatkuva kasaantuminen kaupunkeihin ei näyttänyt olevan sopusoinnussa kansamme terveen ja tasasuhtaisen kehityksen kanssa, liitto alkoi pohtia keinoja asioiden ohjaamiseksi oikeammille raiteille. Kysymyksen käsittelyä vaikeutti kuitenkin se, että muuttoliikettä ja sen syitä oli maassamme tutkittu varsin vähän. Luodakseen lisävalaistusta asiaan ja ennen kaikkea siihen seikkaan, millä tavalla tätä ilmiötä olisi käytännössä tarkoituksenmukaisinta selvitellä, Väestöliitto kesällä 1945 pani alulle muuttoliikettä koskevan tutkimuksen neljässä Kuopion läänin maalaiskunnassa. Jossakin määrin erilaisin perustein sitä sitten seu- 
raavana kesänä jatkettiin yhdeksässä Varsinais-Suomen kunnassa.

Kun tutkimuksen tulokset nyt Kuopion läänin kuntien osalta saatetaan julkisuuteen, on syytä korostaa sitä, että esitys ei pyri antamaan maalta muutosta ja sen syistä mitään tyhjentävää kuvaa. Tarkoituksena on valaista asiaa vain sikäli, kuin kerätty tutkimusaineisto ja virallinen tilastomme asianomaisten kuntien osalta tarjoaa siihen mahdollisuuksia. Käytettävissä oleva sivumäärä asettaa niin ikään esitykselle omat rajoituksensa. Ne tilastotaulukot, joita ei voida julkaista, samoin kuin muukin lähdeaineisto, ovat halukkaiden käytettävissä Väestöpoliittisen tutkimuslaitoksen arkistossa.

\section{Aineiston keruu ja luotettavuus.}

Sitten kun toimeenpantavasta tutkimuksesta ensinnä oli neuvoteltu eräiden alan asiantuntijoiden kanssa, päätettiin heidän suosituksestaan valita tutkimuksen ensimmäisiksi kohteiksi Kuopion läänin kunnat Muuruvesi, Nilsiä, Tuusniemi ja Vieremä, jotka luonnonolojensa sekä talouselämänsä rakenteen puolesta ovat varsin yhdenmukaisia. Kuntia valittaessa pidettiin silmällä, paitsi muuttoliikkeen vilkkautta, myös sitä seikkaa, että kunnassa oli paljon perhelisää saavia perheitä, Väestöliiton tarkoituksena kun oli samalla hankkia selvitys näiden perheiden oloista (ks. seur. kirjoitusta).

Kuhunkin kuntaan lähetettiin oma tutkijansa, Yhteiskunnallisen Korkeakoulun opiskelija, jonka ensimmäisenä tehtävänä oli merkitä tarkoitusta varten painatetuille lomakkeille vuosina 1921-1944 seurakunnasta muuttaneista henkilöistä ne tiedot, jotka muuttaneiden luettelosta oli saatavissa: asianomaisen nimi, sukupuoli, syntymävuosi, ammatti, paikkakunta, jonne muutto oli tapahtunut, sekä kylä, josta asianomainen oli lähtenyt. Lomakkeiden túltua tältä osalta täytetyiksi tutkijain tehtävänä oli kierrellä kylissä ja koettaa saada poismuuttaneiden sukulaisilta, tuttavilta ja muilta paikkakuntalaisilta tietoja heidän poismuuttonsa syistä. Tämä selvitys rajoitettiin kos- 
kemaan vain vuosina 1935-1944 muuttaneita. Kylissä liikkuessaan tutkijoiden oli samalla täytettävä kustakin perhelisäperheestä toinen lomake, jossa selvitettiin näiden perheiden asuntoym. oloja. Tutkijoiden oli myös tarkkailtava kunnan taloudellisia, sosiaalisia, terveydellisiä ja sivistysoloja, joista kukin heistä sitten laati kirjallisen selostuksen.

Tiedustelu koski siis vain seurakunnista muuttaneita, ei siviilirekisteriin kuuluvia. Viimeksi mainittujen osuus muuttoliikkeestä on kuitenkin ollut ko: kunnissa perin vähäinen. Esim. vuosina 1921-1930 heitä muutti Muuruvedeltä vain 15, Nilsiästä 5, Tuusniemeltä 3, Vieremästä ei ainoatakaan. Heitä koskevien tietojen puuttumisen tutkittavana olevasta aineistosta ei siis voida katsoa oleellisesti vaikuttavan tutkimuksen tuloksiin.

Mitä kerätyn aineiston laatuun tulee, on todettava, että tutkijat ovat suorittaneet kirkonkirjojen jäljentämisen tarpeellisella huolella. Samalla he ovat oikaisseet erinäisiä kirjoissa esiintyneitä yhteenlasku- ym. virheitä.

Mutta vaikka kerätty aineisto antaakin melko luotettavat tiedot niistä henkilöistä, joka ko. aikana ovat eri seurakunnista ottaneet muuttokirjan muualle siirtymistä varten, ei aineistomme sen paremmin kuin virallinen väestötilastokaan kykene antamaan 1920-luvun muuttoliikkeestä ja sen vuotuisista vaihteluista oikeaa kuvaa. Sanottuna aikana ei näet likimainkaan kaikista muutoista tehty kirkkoherroille säädettyä ilmoitusta. Vuonna 1898 annetussa seurakunnasta toiseen muuttoa koskevassa asetuksessa oli tosin ilmoituksen laiminlyömisestä säädetty 10 markan suuruinen sakko, mutta se menetti inflaation johdosta 1920-luvulla merkityksensä, ja asian valvontakin lyötiin suurelta osalta laimin. Tämä epäkohta tuli korjatuksi muuttoilmoituksen teosta marraskuun 28 päivänä 1930 annetulla uudella asetuksella, jonka määräysten rikkomisesta voitiin tuomita jopa 50 päiväsakkoon. V. 1931, jonka alussa asetus tuli voimaan, rekisteröityjen muuttotapausten luku nousi kolmin-nelinkertaiseksi edelliseen vuoteen verrattuna, kun edellisellä vuosikymmenellä muuttaneet kiirehtivät tekemään myö- 
hästyneet muuttoilmoituksensa. Sen jälkeen muuttoilmoitus lienee yleensä tehty säädetyn ajan kuluessa, joskin sotavuosina saattoi tässä suhteessa esiintyä laiminlyöntejä tavallista enemmän.

Kun aineisto ei kykene antamaan muuttoliikkeen vuotuisista vaihteluista luotettavaa kuvaa ennen kuin vasta vuodesta 1932 lähtien, kysymys taloudellisten suhdanteitten vaikutuksesta muuttoliikkeeseen on jätetty tämän tutkimuksen ulkopuolelle. Koska suurin osa v. 1931 rekisteröidyistä muuttotapauksista oikeastaan kuuluu aikaisempiin vuosiin, tämä vuosi on eri vuosikymmenien lukuja keskenään vertailtaessa liitetty vuosiin 1921-1930. Toisaalta sotavuosi 1940 on liitetty yhdeksi ryhmäksi sitä seuraavien vuosien kanssa, niin että on saatu ajanjaksot $1921-1931,1932-1939$ ja $1940-1944$. Tästä jaoituksesta on kuitenkin täytynyt erinäisissä tapauksissa poiketa.

Kuntien luonnon- ja väestöolot.

Sijaintija pinnanmuodostus. Muruvesi, Nilsiä ja Vieremä ovat Pohjois-Savossa, kaksi ensiksi mainittua Nilsiän reitin varrella, Vieremä taas Iisalmen reitin latvavesien ympärillä. Tuusniemi sijaitsee Keski-Savon itärajalla, Juojärven länsirannalla, ollen se kuitenkin Muuruveden naapuripitäjä. Lähimpänä kaupunkina on Vieremällä Iisalmi, muilla Kuopio. Yhteydet näihin keskuksiin ovat kokonaan maantieliikenteen tai jäättömänä vuodenaikana myös laivaliikenteen varassa, sillä rautatietä ei ko. kuntien alueella käytännöllisesti katsoen ole, kun Iisalmen-Kontiomäen rata kulkee vain pari kilometriä Vieremän alueella.

Prof. J. G. Granön laatimassa maantieteellisessä aluejaoituksessa luetaan kaikki mainitut kunnat kuuluviksi Järvi-Suomeen, Nilsiä ja Vieremä Kaavin-Vieremän vuoriseutuun, Muuruvesi ja Tuusniemi taas Kuopion mäkiseutuun. ${ }^{1}$

Kuten näistä seutujen nimistäkin jo voi päätellä, pinnanmuodostus on ko. kunnissa hyvin vaihtelevaa, sellaista, mità 
yleensä pidetään Savon luonnolle tyypillisenä. Kukkulat ja harjanteet, laaksot ja notkot vaihtelevat alituisesti keskenään, joten tasaisia pintoja on verraten vähän. Maisemien kauneutta lisää järvien runsaus. Etenkin Muuruvesi on kauttaaltaan vesien pirstomaa seutua.

Kallioperää peittävistä maalajeista on yleisin murtokivi- eli moreenisora, joka kokoomukseltaan on hyvin erilaista. Se sisältää milloin pääasiallisesti suuria kiviä, milloin karkeata ja hienoa soraa, milloin hiekkaa ja lietehiukkasia. Moreenisoran ohella tavataan myös vierinkivisoraa, joka esiintyy paikoitellen korkeinakin harjuina. Näiden ympärillä leviää laajoja mäntyä kasvavia kangasmaita, mutta toisaalta on harjujen välisiin laaksoihin syntynyt monin paikoin myös turvekerrostumia. Etenkin Nilsiän koillisosa on miltei yhtäjaksoisen suoverkoston halkoma. Muista maalajeista on vielä mainittava savi, joka leveämpinä tai kapeampina vöinä leviää vesistöjen rantamilla etenkin Muuruveden keskusreitin varrella, Tuusniemen luoteisosissa sekä Vieremän eteläosassa. ${ }^{2}$

A sutus. Keskimääräisen väentiheyden ollessa v. 1940 Kuopion läänin maaseudulla 9,4 henkeä neliökilometriä kohden se oli Vieremällä vain 7,0 henkeä. Muut ko. kunnat sensijaan olivat läänin keskiarvon yläpuolella, sillä vastaava luku oli Tuusniemellä 10,6, Nilsiässä 12,2 ja Muuruvedellä 13,8 henkeä ${ }^{3}$. Nämä luvut kykenevät kuitenkin antamaan vain heikon kuvan asutuksen todellisesta ryhmittymisestä. Yleensä asutus on keskittynyt vesistöjen rantamille, missä viljavat savikot tarjoavat maanviljelykselle parhaat edellytykset, kun taas laajat metsäseudut niiden ympärillä voivat olla kokonaan asumattomia. Niinpä Vieremä jakaantuu kahteen toisistaan melkoisesti poikkeavaan osaan: eteläosaan, jossa maanlaatuna laajalti on hedelmällinen savi ja joka senvuoksi on sangen taajaan asuttua, sekä väestöstä köyhään pohjoisosaan, joka paikoittain on erämaan kaltaista aluetta. Nilsiän autioimmat seudut ovat sen soista rikkaat koillisosat, jotka ovat vielä miltei alkuperäisessä luonnontilassa, ja muuallakin kunnassa taloryhmät ja viljelysmaat muodostavat useimmiten vain pieniä erillisiä »keitaita» laajojen, 
harvaan asuttujen metsämaiden keskellä. Tuusniemellä on kilometrimääräisiä autioita seutuja ainoastaan pohjoisosassa, Kaavinjärven lounaispuolella, kun taas asutus muualla on levinnyt verraten tasaisesti yli pitäjän. Muuruvedellä ei ole varsinaisia asumattomia sydänmaita lainkaan, mutta täälläkin asutus osoittaa ilmeistä pyrkimystä keskittyä määrättyihin kohtiin, etenkin vesistöjen rantamille. ${ }^{2}$

Vä estönkehitys. Virallisen tilaston mukaan Muuruveden, Nilsiän, Tuusniemen ja Vieremän yhteinen väkiluku on tutkimuksemme kohteena olevana aikana vähentynyt kaikkiaan yli 2000 hengellä. Tämä johtuu kuitenkin suurelta osalta seurakuntien välisistä aluejärjestelyistä, jotka näille kunnille ovat yleensä merkinneet väestönmenetystä. Mutta vaikka jätämmekin nämä tappiot huomioon ottamatta, voimme silti todeta Muuruveden väkiluvun vv. 1921-1944 pienentyneen 404 hengellä, kun taas lisäys on Tuusniemellä ollut 20 , Vieremällä 440 ja Nilsiässä 636 henkeä. Tulos ei siis ole kehuttava, kun ottaa huomioon, että kysymyksessä on neljännesvuosisadan pituinen ajanjakso ja alaltaan sekä asukasluvultaan melko suuret kunnat. Nilsiän väkiluku oli vuoden 1944 päättyessä 8459, Tuusniemen 6744, Vieremän 6635 ja Muuruveden 4174 henkeä 4.

Väkiluvun heikkoon tai takaperoiseen kehitykseen näissä kunnissa ei kuitenkaan ole ollut syynä syntyneisyyden taikka syntyneiden enemmyyden pienuus, kuten monissa muissa osissa maatamme on asian laita. Kuopion läänissä väestön hedelmällisyys on tunnetusti suurempi kuin muualla maassamme Oulun-Lapin lääniä lukuun ottamatta, ja ko. kunnissa se on vielä läänin keskiarvonkin yläpuolella, paitsi Tuusniemen kunnassa, joka sekin silti ylittää koko maan keskiarvon, kuten taulukko 1 osoittaa.

Koska syynä väestönkehityksen heikkouteen ei ole lunnollinen väenlisäys, vian täytyy olla toisessa asiaan vaikuttavassa tekijässä muuttoliikkeessä. Kuten taulukosta 2 voidaan havaita, ko. kuntien yhteinen muuttotappio on vv. 1921-1944 ollut 5495 henkeä, mistä 1310 henkeä tulee Muuruveden, 1807 Nilsiän, 1148 Tuusniemen ja 1230 Vieremän osalle. Selvemmän 
Taulukko 1. Syntyneisyys ja syntyneiden enemmyys keskiväkiluvun 1000 henkeä kohden vv. 1921-1940.

Alue

Syntyneisyys

$$
1921-1930 \quad 1931-1940
$$

Muuruvesi $\ldots \ldots \quad 26,4$

Nilsiä ......... 29,3

Tuusniemi $\quad \ldots \ldots .25,4$

$\begin{array}{llll}\text { Vieremä } \ldots \ldots \ldots & 28,7\end{array}$

Kuopion lääni ‥ 26,0

Koko maa ...... 22,2

22,9
24,3
21,8
24,9
22,4
18,6

Syntyneiden enemmyys $1921-1930 \quad 1931-1940$

Taulukko 2. Muuruveden, Nilsiän, Tuusniemen ja Vieremän kuntien muuttoliike vv. 1921-1944. ${ }^{5}$

\begin{tabular}{|c|c|c|c|c|c|c|c|c|c|}
\hline \multirow{2}{*}{$\begin{array}{l}\text { Ajanjakso } \\
\text { ja kunta }\end{array}$} & \multicolumn{3}{|c|}{$\begin{array}{c}\text { Kuntaan muut- } \\
\text { taneet }\end{array}$} & \multicolumn{3}{|c|}{$\begin{array}{c}\text { Kunnasta muut- } \\
\text { taneet }\end{array}$} & \multicolumn{3}{|c|}{$\begin{array}{c}\text { Muuttovoitto }(+) \text { tai } \\
\text { tappio }(-)\end{array}$} \\
\hline & $\frac{3}{9}$ & $\begin{array}{c}z \\
\frac{0}{0} \\
\frac{0}{0} \\
\end{array}$ & 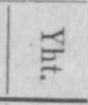 & $\frac{3}{8}$ & 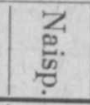 & 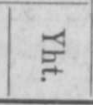 & $\frac{3}{8}$ & 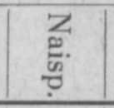 & $\rightleftarrows$ \\
\hline $1921-$ & & & & & & & & & \\
\hline $\begin{array}{l}\text { Muuruvesi } \ldots . . \\
\text { Nilsiä } \ldots . . . . . . \\
\text { Tuusniemi } \\
\text { Vieremä ....... } \\
\end{array}$ & $\begin{array}{l}535 \\
622 \\
470 \\
426 \\
\end{array}$ & $\begin{array}{l}801 \\
932 \\
611 \\
639 \\
\end{array}$ & $\begin{array}{l}1336 \\
1554 \\
1081 \\
1065 \\
\end{array}$ & $\begin{array}{r}832 \\
1131 \\
855 \\
696 \\
\end{array}$ & $\begin{array}{l}1187 \\
1547 \\
1042 \\
1005 \\
\end{array}$ & $\begin{array}{l}2019 \\
2678 \\
1897 \\
1701 \\
\end{array}$ & $\begin{array}{r}-297 \\
-509 \\
-385 \\
-270 \\
\end{array}$ & $\begin{array}{l}-386 \\
-615 \\
-431 \\
-366\end{array}$ & $\begin{array}{r}-68 \\
-112 \\
-81 \\
-63 \\
\end{array}$ \\
\hline Yhteensä & 2053 & 2983 & 5036 & $\mid 3514$ & 4781 & 8295 & -1461 & -1798 & -325 \\
\hline 1932-1939: & & & & & & & & & \\
\hline $\begin{array}{l}\text { Muuruvesi } \\
\text { Nilsiä } \ldots \ldots . . . . . . \\
\text { Tuusniemi } \\
\text { Vieremä ............ }\end{array}$ & $\begin{array}{l}302 \\
611 \\
523 \\
389 \\
\end{array}$ & $\begin{array}{l}578 \\
961 \\
672 \\
575 \\
\end{array}$ & $\begin{array}{r}880 \\
1572 \\
1195 \\
964 \\
\end{array}$ & $\begin{array}{l}558 \\
848 \\
648 \\
588 \\
\end{array}$ & $\begin{array}{r}845 \\
1319 \\
882 \\
885 \\
\end{array}$ & $\begin{array}{l}1403 \\
2167 \\
1530 \\
1473 \\
\end{array}$ & $\begin{array}{l}-256 \\
-237 \\
-125 \\
-199 \\
\end{array}$ & $\mid \begin{array}{r}-267 \\
-358 \\
-210 \\
-310\end{array}$ & $\begin{array}{l}-523 \\
-595 \\
-335 \\
-509 \\
\end{array}$ \\
\hline Yhteensä & 1825 & 2786 & 4611 & 2642 & 3931 & 6573 & $|-817|$ & $\mid-1145$ & -1962 \\
\hline $\begin{array}{l}\text { Muuruvesi } \\
\text { Nilsiä } \ldots . . . . . . \\
\text { Tuusniemi } \\
\text { Vieremä } \ldots \\
\end{array}$ & $\begin{array}{l}149 \\
325 \\
262 \\
225 \\
\end{array}$ & $\begin{array}{l}338 \\
588 \\
453 \\
422 \\
\end{array}$ & $\begin{array}{l}487 \\
913 \\
715 \\
647 \\
\end{array}$ & $\begin{array}{l}219 \\
374 \\
270 \\
258 \\
\end{array}$ & $\begin{array}{l}372 \\
627 \\
442 \\
474 \\
\end{array}$ & $\begin{array}{r}591 \\
1001 \\
712 \\
732 \\
\end{array}$ & $\begin{array}{r}-70 \\
-49 \\
-8 \\
-33 \\
\end{array}$ & $\begin{array}{r}-34 \\
-39 \\
+11 \\
-52 \\
\end{array}$ & $\begin{array}{r}-104 \\
-\quad 88 \\
+\quad 3 \\
-\quad 85 \\
\end{array}$ \\
\hline Yhteensá & 961 & 1801 & 2762 & 1121 & 1915 & $\mid 3036$ & $|-160|$ & $|-114|$ & $\mid-274$ \\
\hline
\end{tabular}


Taulukko 3. Kuntien muuttotappio \%:na syntyneiden enemmyydestä vv. 1921-1944.

$\begin{array}{lccccc}\text { Ajanjakso } & \text { Muuruvesi } & \text { Nilsiä } & \text { Tuusniemi } & \text { Vieremä } & \text { Yhteensä } \\ 1921-1931 & 115 & 91 & 105 & 66 & 91 \\ 1932-1939 & 172 & 81 & 81 & 85 & 96 \\ 1940-1944 & 135 & 39 & - & 56 & 49 \\ 1921-1944 & 134 & 82 & 88 & 72 & 89\end{array}$

Taulukko 4. Muuttaneiden luku keskiväkiluvun 1000 henkeä kohden vv. 1921-1944.

Kunta
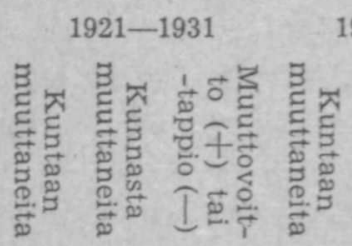

$1932-1939$

$1940-1944$

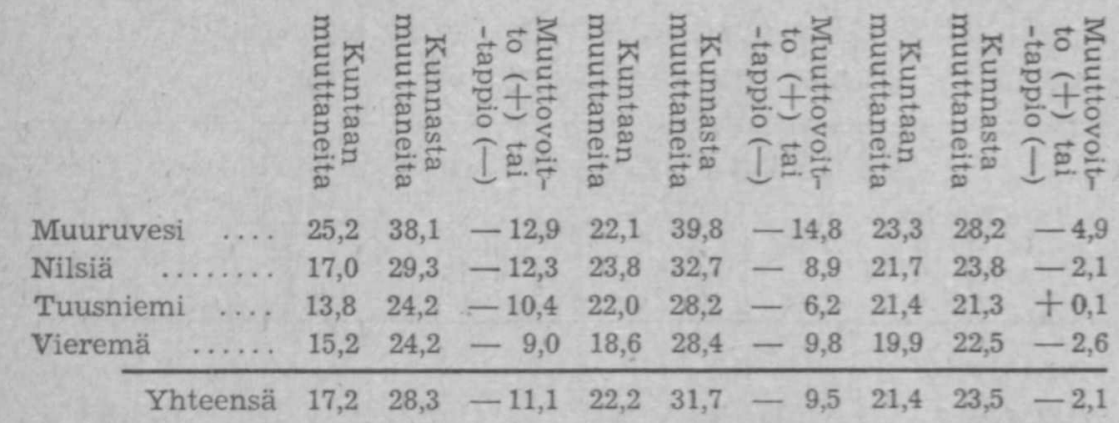

kuvan niistä menetyksistä, mitä muuttoliike on eri kunnille tuottanut, antaa taulukko 3 , jossa kunkin kunnan muuttotappioita on verrattu niiden luonnolliseen väenlisäykseen.

Muuruveden muuttotappio on jatkuvasti ollut sen luonnollista väenlisäystä suurempi. Tässä suhteessa se merkittävällä tavalla poikkeaa muista ko. kunnista, joissa syntyneiden enemmyys ainoastaan Tuusniemellä vv. 1921-1931 jää muuttotappiota pienemmäksi. Tutkimuksemme kohteena olevana aikana Tuusniemi on muuttotappion muodossa menettänyt luonnollisesta väestölisäyksestään lähes $9 / 10$, Nilsiä yli $4 / 5$ ja Vieremä lähes $3 / 4$, kun taas Muuruvesi on menettänyt sen kokonaan sekä lisäksi vielä 404 henkeä. Kuntien yhteinen keskimääräinen tappio on ollut noin $9 / 10$ syntyneiden enemmyydestä. 
Muuttovirran voimakkuus, suunta ja kokoomus.

Väestön liikkuvuus. Muuttoliikkeen vilkkauden osoittamiseksi on taulukossa 4 virallisen väestönmuutostilaston pohjalla esitetty, suuriko muuttaneiden luku eri ajanjaksoina on ollut kuntien keskiväkiluvun 1000 henkeä kohden. Aluejärjestelyjen yhteydessä seurakunnasta toiseen siirretyt on jätetty huomioon ottamatta.

Verratessamme kunnasta muuton vilkkautta vuosina 19211931 ja 1932 - 1939, voimme todeta sen kaikissa kunnissa jälkimmäisenä ajanjaksona lisääntyneen. Muuruvedellä, joka edellisenä kautena oli tässä suhteessa tuntuvasti edellä muista, lisäys kuitenkin jäi melko vähäiseksi. Myöskin kuntaan muutto lisääntyy vv. 1932-1939 aikaisempiin vuosiin verrattuna muissa kunnissa paitsi Muuruvedellä, jossa se alenee. Vieremällä samoin kuin Muuruvedelläkin muuttotappio jälkimmäisenä ajanjaksona suurenee, kun se taas Nilsiässä ja Tuusniemellä pienenee. Mitä sotavuosien 1940-1944 lukuihin tulee, niille on ominaista suhteellisen vähäinen kunnasta ja suhteellisen runsas kuntaan muutto, mistä johtuen muuttotappiokin jää alhaiseksi, muuttuupa se Tuusniemen osalta vähäiseksi muuttovoitoksikin.

Kuntien keskinäinen vertailu osoittaa Muuruveden monessa suhteessa poikkeavan muista kolmesta. Kunnasta muuton suuruuden puolesta se on aina ollut muista tuntuvasti edellä, samoin kuntaan muuttoonkin nähden, jos jätämme vuodet 1932-1939 lukuun ottamatta. Muuruvesi on siis suuremmassa määrässä kuin muut kunnat ollut eräänlaisena väestön kauttakulkupaikkana. Mutta tämä muuttovirta on samalla vienyt mennessään huomattavat määrät Muuruveden kantaväestöäkin. Muuttotappion suuruuteen nähden se on aina ollut ensi tilalla, ja etenkin vv. 1932-1944 se on tässä suhteessa tuntuvasti edellä muita kuntia. Vuosina 1932-1939 Muuruvesi menetti muuttoliikkeen takia vuosittain keskimäärin $1,5 \%$ väestöstään kuntien yhteisen keskimääräisen tappion ollessa noin 1,0\%. Ajanjaksona 1921 -1931 vastaavat luvut olivat 1,3 ja $1,1 \%$. 
Muuttaneiden sukupuoli. Muuttoliikettä koskevissa tutkimuksissa on yleensä tehty se havainto, että naiset muodostavat muuttaneiden enemmistön. ${ }^{6} \quad$ Nyt kysymyksessä olevat kunnat eivät tässä suhteessa ole minään poikkeuksena, kuten taulukosta 5 voidaan todeta.

Taulukko 5. Mies- ja naispuoliset muuttajat keskiväkilukunsa 1000 henkeä kohden vv. 1921-1944.

Kunta
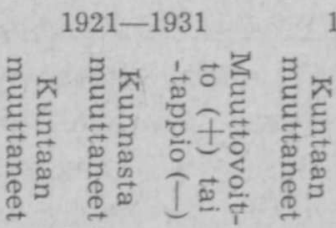

$1932-1939$

$1940-1944$

Miespuoliset:
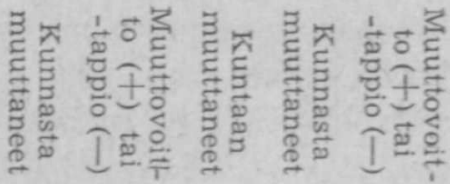

$\begin{array}{lllllllllll}\text { Muuruvesi } & \ldots & 19,9 & 30,9 & -11,0 & 16,7 & 30,8 & -14,1 & 14,2 & 20,9 & -6,7\end{array}$ Nilsiä $\quad \ldots \ldots \ldots . \quad 13,4 \quad 24,4-11,0 \quad 17,9 \quad 24,8-6,9 \quad 15,1 \quad 17,4 \quad-2,3$

$\begin{array}{lllllllllllll}\text { Tuusniemi } & \ldots & 11,7 & 21,3 & - & 9,6 & 18,4 & 22,8 & - & 4,4 & 9,8 & 10,1 & -0,3\end{array}$

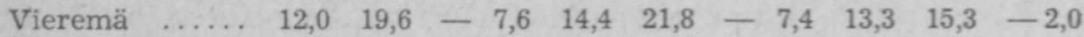

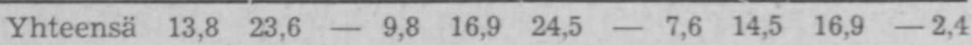

Naispuoliset:

$\begin{array}{lllllllllll}\text { Muuruvesi } & \ldots & 30,8 & 45,6 & -14,8 & 33,7 & 49,3 & -15,6 & 32,4 & 35,6 & -3,2\end{array}$

$\begin{array}{llllllllllll}\text { Nilsiä } & \ldots \ldots & 20,7 & 34,3 & -13,7 & 30,1 & 41,3 & -11,2 & 28,7 & 30,6 & -1,9\end{array}$

Tuusniemi $\ldots . \quad 16,0 \quad 27,2-11,2 \quad 25,9 \quad 34,0-8,1 \quad 28,2 \quad 27,6 \quad 0,6$

\begin{tabular}{lllllllllll} 
Vieremä & $\ldots \ldots$ & 18,5 & 29,1 & $-10,6$ & 23,2 & 35,7 & $-12,5$ & 26,9 & 30,2 & $-3,3$ \\
\hline
\end{tabular}

$\begin{array}{llllllllll}\text { Yhteensä } & 20,7 & 33,2 & -12,5 & 27,9 & 39,4 & -11,5 & 28,7 & 30,6 & -1,8\end{array}$

Miesten ja naisten suhdelukujen vertailu osoittaa, että ko. luvut rauhan vuosina poikkeuksetta olivat suuremmat naisten kuin miesten osalta, vieläpä hyvin tuntuvastikin. Niinpä naisten kuntaan muutto oli vv. 1932-1939 Muuruvedellä yli kaksi kertaa niin suuri kuin miesten. Vielä ylivoimaisempi naisten luku oli vuosina 1940 - 1944, jolloin parhaassa työkykyisessä iässä olevat miehiset ikäluokat sotapalveluksen tai työvelvollisuuden johdosta olivat suurelta osalta estyneet muuttoliikkeeseen osallistumasta. Muuttotappio sensijaan oli näinä vuosina 
miesten osalta suhteellisesti suurempi kuin naisten, Vieremän kuntaa lukuun ottamatta.

Verratessamme toisiinsa ajanjaksoja 1921 - 1931 ja 1932 1939 voimme todeta, että kunnasta muutto on jälkimmäisenä kautena lisääntynyt miesten osalta varsin vähän, onpa se Muuruvedellä vähän pienentynytkin. Naisten osalta lisäys sensijaan on tuntuvampi sekä kunnasta että kuntaan muuttoon nähden. Heidän muuttotappionsa alenee jonkin verran, ei kuitenkaan samassa määrässä kuin miesten.

Kuntien keskinäinen vertailu osoittaa jälleen, miten suuresti Muuruvesi muuttoliikkeensä pủolesta eroaa muista kunnista. Sen suhdeluvut ovat sekä miesten että naisten osalta suurimmat, olipa sitten kysymyksessä kuntaan tai kunnasta muutto taikka muuttotappio. Rauhan vuosina oli ainoana poikkeuksena se, että miesten kuntaan muutto oli vv. 1932-1939 Muuruvedellä pienempi kuin kunnissa keskimäärin, jota paitsi Nilsiä pääsi miesten suhteellisessa muuttotappiossa vv. 1921-1931 samaan tulokseen kuin Muuruvesikin. Vieremä, jonka suhteellinen muuttotappio ensimmäísenä ajanjaksona oli alhaisin, nousi vv. 1932 - 1939 tässä suhteessa toiseksi ja sivuutti naisten muuttotappion suuruudessa vv. 1940 - 1944 Muuruvedenkin. Merkille pantavan korkea Muuruveden muuttotappio sekä miesten että naisten osalta oli vv. 1932 - 1939 ja samoin miesten osalta 1940 - 1944 .

Kun naisten muuttotappio normaalisina aikoina on poikkeuksetta ollut suurempi kuin miesten, naisten osuus koko väestöstä on jatkuvasti alentunut. Vuonna 1920 he muodostivat $49,5 \%$ kuntien yhteisestä väkiluvusta, mutta v. 1931 vastaava luku oli 48,4 ja v. 1939 vain 47,8\%. Sotavuosien ansiosta heidän osuutensa väestöstä kuitenkin vuoden 1944 päättyessä jälleen nousi 48,9\%:iin.

Yleisenä toteamuksena edellä esitetystä voimme siis sanoa, että naisten liikkuvuus rauhan vuosina oli suurempi kuin miesten ja että se oli jatkuvasti nousemassa.

Mu uton määränpää. Käydeșsämme nyt lähemmin selvittelemään sitä muuttoliikettä, joka ko. kunnissa on suuntautunut muualle Suomeen, tutkimuksen pohjana on etupäässä 
Väestöliiton toimesta kerätty seikkaperäisempi aineisto, jonka luvut vähän poikkeavat virallisen tilaston luvuista, kuten edellä on jo mainittu. Ko. kunnista muuttaneet eivät tietenkään ole kaikki niissä syntyneitä, vaan melkoinen osa heistä on väkeä. joka ahkeraan siirtyy talosta tai kunnasta toiseen. Monet heistä voivat tulla saman seurakunnan muuttaneiden luetteloon useampaankin kertaan lyhyemmin tai pitemmin väliajoin. Muuttoliikkeen kaikinpuolisen selvittelyn kannalta olisi ollut eduksi hankkia henkilötiedot kunnasta muuttaneiden ohella myöskin kuntaan muuttaneista, mutta tälle seikalle ei tutkimusta suunniteltaessa osattu antaa tarpeeksi suurta merkitystä.

Sen paikkakunnan mukaan, jolle muutto on tapahtunut, kunnasta muuttaneet on taulukossa 6 jaettu kolmeen ryhmään, nim. kaupunkeihin, naapurikuntiin ja muihin maalaiskuntiin muuttaneisiin. Tiedot on esitetty kuntien yhteislukuina sekä erikseen rauhan ja sodan ajalta.

Taulukko 6. Muuttaneiden jakaantuminen määräpaikkansa perusteella eri kuntaryhmien kesken vv. 1921-1939 ja 1940-1944.

\begin{tabular}{|c|c|c|c|c|c|c|}
\hline & & $21-19$ & & & $40-19$ & \\
\hline Muuton määränpää & $\begin{array}{l}\frac{3}{8} \\
\frac{8}{0} \\
\frac{0}{0} \\
\frac{0}{0}\end{array}$ & 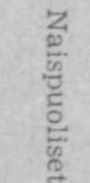 & 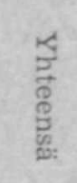 & $\begin{array}{l}\frac{3}{8} \\
\frac{8}{8} \\
\frac{0}{0} \\
\frac{0}{0}\end{array}$ & 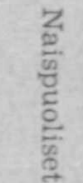 & 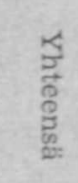 \\
\hline & $\%$ & $\%$ & $\%$ & $\%$ & $\%$ & $\%$ \\
\hline Kaupunki $\quad . . . \ldots$. & 25,6 & 28,3 & 27,2 & 22,0 & 24,1 & 23,3 \\
\hline Naapurikunta .... & 38,5 & 36,7 & 37,4 & 35,3 & 31,9 & 33,1 \\
\hline Muu maalaiskunta & 35,9 & 35,0 & 35,4 & 42,7 & 44,0 & 43,6 \\
\hline Yhteensä & 100 & 100,0 & 100,0 & 100,0 & 100,0 & 100,0 \\
\hline
\end{tabular}

Rauhan vuosina yli neljäsosa kunnasta muuttaneista siirtyi kaupunkeihin. Muut kolme neljäsosaa jakaantuivat melko tasan naapurikuntien ja muiden maalaiskuntien kesken ensiksi mainittujen kuitenkin saadessa vähäisen enemmistön. Sota- 
vuosina kaupunkeihin muuttaneiden osuus supistuu $23 \%$ :iin ja naapurikuntiinkin muuttaneiden määrä pienenee vajuan kolmannekseen, kun taas muihin maalaiskuntiin muutto tulee suhteellisesti entistä paljon vilkkaammaksi. Tähän suunnanmuutokseen ovat epäilemättä vaikuttaneet toisaalta kaupunkien sodanaikaiset ilmapommitukset ja niissä vallinnut elintarvike- ja asuntopula, toisaalta sotavuosina ilmennyt ankara työvoiman tarve, joka maataloudessa oli suuremmassa mitassa kuin esim. teollisuudessa koetettava tyydyttää vapaaehtoista tietä ilman työviranomaisten apua.

Monissa ulkomailla suoritetuissa tutkimuksissa on todettu, että naisten osuus muuttoliikkeestä säännöllisesti vähenee muuttomatkan pidentyessä ${ }^{7}$. Toisin on kuitenkin ollut asian laita tutkimuksemme kohteena olevissa kunnissa. Sekä sodan että rauhan vuosina on naapurikuntiin muuttaneiden naisten osuus ollut pienempi kuin miesten, kun taas naiset kaupunkeihin muuttaneiden joukossa ovat olleet edustettuina suhteellisesti runsaammin, samoin vv. 1940-1944 myös etäisempiin maalaiskuntiin muuttaneiden ryhmässä.

Taulukko 7. Yksityisistä kunnista muuttaneiden jakaantuminen eri kuntaryhmien kesken vv. 1921-1939.

\begin{tabular}{|c|c|c|c|c|c|c|c|c|c|c|c|c|}
\hline \multirow{2}{*}{$\begin{array}{c}\text { Muuton } \\
\text { määränpää }\end{array}$} & \multicolumn{3}{|c|}{ Muuruvesi } & \multicolumn{3}{|c|}{ Nilsiä } & \multicolumn{3}{|c|}{ Tuusniemi } & \multicolumn{3}{|c|}{ Vieremä } \\
\hline & Mp. & Np. & Yht. & Mp. & Np. & Yht. & Mp. & Np. & | Yht. & Mp. & Np. & Yht. \\
\hline Kaupunki & 26,1 & 25,6 & 25,8 & 28,3 & 30,4 & 29,5 & 26,3 & 28,3 & 27,4 & 20,3 & 28,0 & 24,9 \\
\hline $\begin{array}{l}\text { kunta } \\
\text { Muu maa- }\end{array}$ & 39,0 & 40,0 & 39,6 & 32,2 & 30,8 & 31,4 & 41,2 & 37,8 & 39,2 & 44,7 & 41,1 & 42,6 \\
\hline laiskunta & 34,9 & 34,4 & 34,6 & 39,5 & 38,8 & 39,1 & 32,5 & 33,9 & 33,4 & 35,0 & 30,9 & 32,5 \\
\hline
\end{tabular}

Yksityisten kuntien muuttonumerot eroavat jossakin määrin toisistaan, kuten taulukko 7 osoittaa. Naapurikuntiin muutto on Nilsiästä ollut suhteellisesti paljon pienempää kuin muista kunnista, kun taas muihin maalaiskuntiin sekä kaupunkeihin muut_ 
to on ollut sieltä vilkkainta. Suhteellisesti vähäisintä kaupunkeihin muutto on ollut Muuruvedeltä ja Vieremältä, mutta naapurikuntiin muuttoon nähden ne ovat olleet ensi tiloilla.

Muuruveden muista poikkeava luonne ilmenee jälleen siinä, että naapurikuntiin muutto sieltä on naisten osalta ollut suurempi ja kaupunkeihin muutto pienempi kuin miesten osalta, siis päinvastoin kuin muissa kunnissa on asian laita. Tämä johtuu ainakin osaksi siitä vetovoimasta, mikä Juankosken tehdaspaikkakunnalla näyttää olleen naispuolisiin muuttajiin. Juankoski, joka aikaisemmin kuului erityisenä tehdasseurakuntana Muuruveden yhteyteen, muodostettiin itsenäiseksi seurakunnaksi v. 1923. Jos jätämme tästä aiheutuneissa aluejärjestelyissä seurakunnasta toiseen siirretyt huomioon ottamatta, Muuruvedeltä muutti Juankoskelle vv. 1921-1939 kaikkiaan 262 henkeä, joista 148 eli $56 \%$ oli naisia.

Siirtyessämme sitten tarkastelemaan miten kaupunkeihin siirtyneet ovat jakaantuneet eri kaupunkien kesken (taulukko 8), voimme ensinnäkin panna merkille, että rauhan vuosina heistä tuli lähes kolme viidesosaa oman läänin kaupunkien, vajaa viidennes Helsingin ja runsas viidennes muiden kaupunkien osalle. Sotavuosina viimeksi mainitun kaupunkiryhmän osuus pieneni molempien muiden hyväksi siten, että kaupunkeihin muutto tällöin entistä tarkemmin jakaantui eri ryhmien kesken mainittujen murto-osien mukaisesti.

Taulukko 8. Kunnasta muuttaneiden jakaantuminen eri kaupunkien kesken vv. 1921-1939 ja 1940-1944.

$$
\text { 1921-1939 }
$$

$$
1940-1944
$$

Muuton määränpää

Jokin Kuopion läänin

Miesp. Naisp. Yhteensä Miesp.

$$
\% \quad \%
$$

$\%$

Naisp. Yhteensä

kaupunki ..........

Helsinki .......... 13,3

Muu kaupunki ..... 24,9

Yhteensä

$\begin{array}{lll}61,8 & 55,5 & 57,9\end{array}$

$22,0 \quad 18,6$

62,1

16,9

60,4

61,0

22,5

23,5

100,0

100,0

21,0

20,8

19,4

100,0

100,0

100,0

100,0

19,6 
Taulukko 8 vahvistaa toisaalta sen edellä esitetyn toteamuksen, että muuton pituudella ei ole enää - ei ainakaan nyt kysymyksessä olevissa kunnissa - naisten muuttoliikkeelle samaa merkitystä kuin mahdollisesti aikaisemmin. Tämä ilmenee $\mathrm{mm}$. siinä, että kaupunkeihin muuttaneista naisista tulee Helsingin osalle tuntuvasti suurempi prosenttimäärä kuin vastaavista miehistä. Rauhan vuosina kaupunkeihin muuttavista naisista suunnilleen joka viides suuntasi matkansa pääkaupunkiin, miehistä vain joka kahdeksas. Oman läänin kaupunkeihin naiset sensijaan tunsivat paljon vähäisempää vetoa kuin miehet, mutta maan muihin kaupunkeihin nähden ero ei ollut yhtä suuri.

Rauhan ajan kaupunkiin muuttoa on seikkaperäisemmin tarkasteltu taulukossa 9 kunkin kunnan osalta erikseen.

Taulukko 9. Yksityisistä kunnista muuttaneiden jakaantuminen eri kaupunkien kesken vv. 1921-1939.

\begin{tabular}{|c|c|c|c|c|c|c|c|c|c|c|c|c|}
\hline \multirow{2}{*}{$\begin{array}{c}\text { Munton } \\
\text { määränpää }\end{array}$} & \multicolumn{3}{|c|}{ Muuruvesi } & \multicolumn{3}{|c|}{ Nilsiä } & \multicolumn{3}{|c|}{ Tuusniemi } & \multicolumn{3}{|c|}{ Vieremä } \\
\hline & Mp. & Np. 1 & Yht. & Mp. & Np. & |Yht. & Mp. & Np. & Yht. & Mp. & Np. 1$)$ & Yht. \\
\hline $\begin{array}{l}\text { Jokin Kuo- } \\
\text { pion lään. } \\
\text { kaupunki } \\
\text { Helsinki } \\
\text { Muu kau- }\end{array}$ & $\begin{array}{l}62,7 \\
14,8\end{array}$ & $\begin{array}{l}60,4 \\
17,9\end{array}$ & $\begin{array}{l}61,4 \\
16,6\end{array}$ & $\begin{array}{l}61,0 \\
12,5\end{array}$ & $\begin{array}{l}56,2 \\
25,0\end{array}$ & \begin{tabular}{|}
58,1 \\
20,1
\end{tabular} & \begin{tabular}{|l|}
66,7 \\
14,5
\end{tabular} & $\begin{array}{l}55,7 \\
25,5\end{array}$ & $\begin{array}{l}60,2 \\
21,0\end{array}$ & $\begin{array}{l}55,2 \\
11,1\end{array}$ & $\begin{array}{l}49,2 \\
17,4\end{array}$ & $\begin{array}{l}51,2 \\
15,3\end{array}$ \\
\hline punki & 22,5 & 21,7 & 22,0 & 26,5 & 18.8 & 21,8 & $\begin{array}{l}8,8 \\
\end{array}$ & 18,8 & 18,8 & 33,7 & 33,4 & 33,5 \\
\hline
\end{tabular}

Oman läänin kaupunkeihin suuntautuneesta muuttoliikkeestä on - vaikka se ei ilmene edellä esitetyistä luvuista - ylivoimaisesti suurin osa kulkenut lähimpään kaupunkiin, jona Vieremään nähden on Iisalmi ja muiden kolmen kunnan kohdalta Kuopio. Mikäli kysymyksessä on muutto johonkin toiseen läänin kaupungeista, "vieremäläiset valitsevat useimmiten Kuopion ja muiden kuntien asukkaat Iisalmen, kun taas muutot läänin kolmanteen kaupunkiin Joensuuhun ovat näistä kunnista verraten harvinaisia. 
Merkille pantavaa muuten on, että oman läänin kaupunkeihin muutto on Vieremältä ollut tuntuvasti pienempi kuin muista ko. kunnista, kun taas maan muihin kaupunkeihin (Helsinkiä lukuun ottamatta) sieltä on muutettu erittäin vilkkaasti. Tämä johtuu lähinnä siitä, että Vieremältä ei ole pitkä matka myöskään Oulun läänin puolella sijaitsevaan Kajaanin kaupunkiin, joka siten esiintyy Iisalmen pahimpana kilpailijana. Kaikkiaan muutti Vieremältä vv. 1921-1944 Iisalmeen 393 ja Kajaaniin 132 henkeä.

Helsinkiin muutto on ollut vilkkainta Tuusniemeltä ja Nilsiästä, kun taas Muuruvesi ja Vieremä jäävät tässä suhteessa melkoisesti jälkeen niistä. Mitä maan muihin kaupunkeihin tulee, niistä ovat ko. kuntien asukkaita ennen kaikkea vetäneet puoleensa Viipuri, Kotka, Lahti ja Tampere. Muuruvedeltä on muutettu myös melkoisesti Jyväskylään ja Raumalle, Nilsiästä Jyväskylään, Savonlinnaan ja Sortavalaan ja Vieremältä Kajaanin ohella Vaasaan. Karjalan joutuminen sotatoimialueeksi syksyllä 1939 ja seuraavana vuonna tapahtunut Viipurin, Käkisalmen ja Sortavalan luovutus Neuvostoliitolle ovat osaltaan vaikuttaneet siihen, että Kuopion läänin kaupunkien ja Helsingin osuus muuttoliikkeestä vv. 1940-1944 kasvaa sodanedellisiin vuosiin verrattuna.

Mu uttaneiden ikä. Taulukko 10 esittää kaupunkøihin muuttaneiden ikäryhmityksen ja taulukko 11 heidän suhteellisen jakaantumisensa eri ikäryhmien kesken. Viimeksimainittuun taulukkoon on otettu vastaavat prosenttiluvut myöskin maalaiskuntiin muuttaneiden osalta. Niitä laskettaessa on Muuruvedeltä vv. $1921-1930$ ja Tuusniemeltä vv. 1921-1939 maalaiskuntiin muuttaneet jätetty huomioon ottamatta, kun näiden ikää koskevat tiedot ovat puutteellisia.

Kaupunkeihin muuttaneiden miesten absoluuttinen luku on rauhan vuosina ollut naisten vastaavaa lukua alhaisempi kaikissa muissa ikäluokissa paitsi 30 -34-vuotiaitten ryhmässä, jossa kumpikin luku on suunnilleen yhtä suuri, ja 35-39-vuotiaitten ryhmässä, jossa miehiä on enemmän. Sotavuosina mies- 
ten enemmyyttä esiintyy kaikkiaan kolmessa keskisessä ikäryhmässä, nim. 30-49-vuotiaitten luokissa. Viittätoista vuotta nuoremmista naispuoliset muodostavat vain vähäisen enemmistön, mutta 15-19-vuotiaitten ryhmässä heitä on jo rauhan vuosina suunnilleen neljä kertaa niin paljon kuin miehiä. Sitä vanhemmissa ikäluokissa heidän ylivoimaisuutensa heikkenee noustakseen sitten taas 40 . ikävuodesta lähtien.

Taulukko 10. Kaupunkeihin vv. 1921-1944 muuttaneiden ikäryhmitys.

Muttaneiden luku

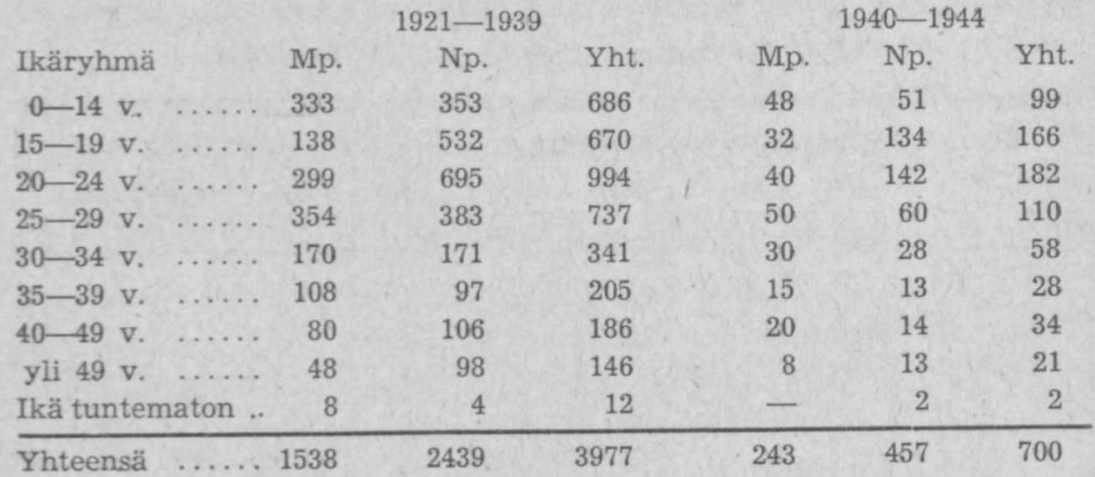

Kaikista kaupunkeihin muuttaneista oli rauhan vuosina 25 $\%$, sotavuosina $26 \% 20-24$-vuotiaita. Tämä ikäryhmä muodostaa eräänlaisen huipun, josta käsin ko. prosenttiluku rauhan vuosina säännöllisesti alenee sekä nuorempiin että vanhempiin ikäluokkiin siirryttäessä. Kaikkein nuorimman ikäryhmän suhdeluku tosin on vähän suurempi kuin 15-19-vuotiaitten, mutta edelliseen kuuluukin kaikkiaan 14 ja jälkimmäiseen vain 5 vuosiluokkaa.

Ko. suhdeluvut poikkeavat kuitenkin miesten ja naisten osalta tuntuvasti toisistaan. Tavallisin muuttoikä on naisilla 20 24, miehillä 25-29 vuotta, mutta paljon niistä jälkeen eivät jää lähinnä nuoremmat ikäryhmätkään. Erityisesti on panta- 
va merkille, miten nuorina tytöt jo jättävät kotinsa ja lähtevät maailmalle. Naispuolisista kaupunkeihin muuttajista oli rauhan vuosina $21,8 \%$ ja sotavuosina peräti $29,3 \%$ 15-19-vuotiaita, miespuolisista vastaavasti vain $9,0-13,2 \%$. Se seikka, että kaupunkeihin muuttaneista 15-19-vuotiaista noin neljä viideosaa on tyttöjä ja vain yksi viidesosa poikia, osoittaa suurimman osan tytöistä siirtyvän kaupunkiin yksin ilman vanhempiensa tukea ja valvontaa. Kaupunkeihin muuttaneissa perheissä näet on ollut suunnilleen yhtä paljon poikia kuin tyttöjäkin, kuten taulukosta 13 voidaan todeta.

Taulukico 11. Eri ikäluokkien prosentuaalinen osuus muuttaneiden kokonaismäärästä vv. 1921-1944.

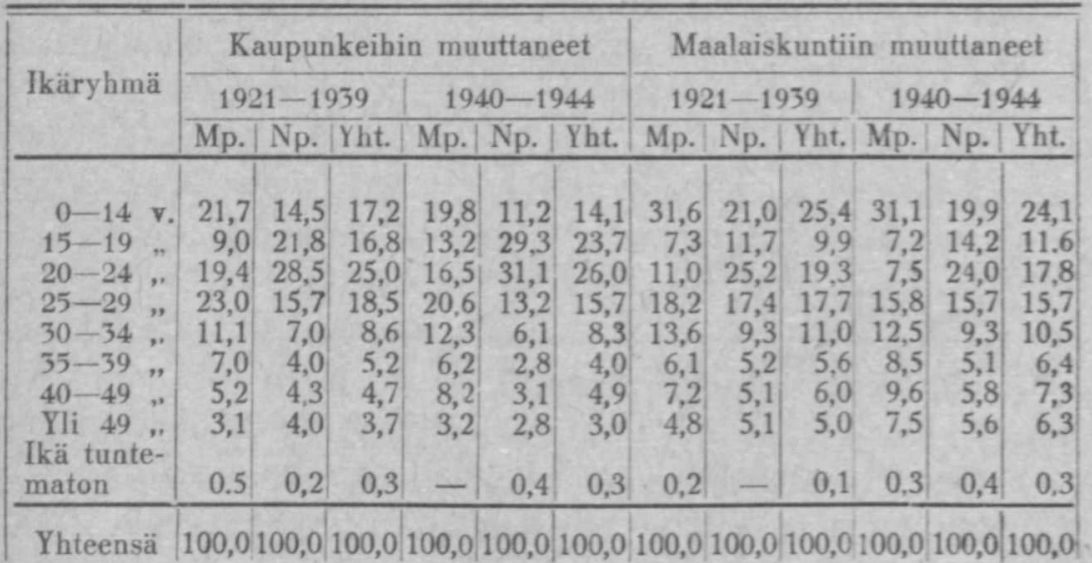

Taulukon 11 suhdeluvut vahvistavat osaltaan sen yleisesti vallitsevan käsityksen, että nuorisolla on muuttoliikkeessä hallitseva asema. Rauhan vuosina oli ko. kunnista kaupunkeihin muuttaneista miespuolisista yli puolet $(53,5 \%) 20-34$-vuotiaita, naispuolisista taas suunnilleen kaksi kolmasosaa $(66 \%$ \% $15-29$ vuotiaita. Sotavuosina nuorten miesten osuus supistui 49,4 $\%$ :iin, kun taas naisten vastaava luku nousi $73,6 \%$ :iin. Mainittakoon vielä, että ko. ikäluokat muodostavat vain noin nel- 
jännen osan $(25,4-27,2 \%)$ kuntien koko mies-, vastaavasti naispuolisesța väestöstä.

Samat piirteet, jotka edellä on esitetty tunnusomaisiksi kaupunkiin muuttaneiden ikäryhmitykselle, on todettavissa myös maalaiskuntiin muuttaneissa, joskin jonkin verran heikompina. Tavallisin muuttoikä tässäkin tapauksessa on - jos jätämme lapset huomioon ottamatta - miehillä $25-29$ vuotta ja naisilla 20-24 vuotta, mutta toisella tilalla ovat näitä lähinnä vanhimmat viisivuotisryhmät, ei siis lähinnä nuorimmat, kuten asian laita oli kaupunkeihin muuttaneisiin nähden. Maalaiskuntiin muuttaneista miehistä kuului 20-34-vuotiaisiin rauhan aikana 42,8 ja sotavuosina $35,8 \%$, ja $15-29$-vuotiaitten naisten osalta vastaavat luvut olivat 54,3 ja $53,9 \%$, kaikki luvut siis tuntuvasti alhaisemmat kuin kaupunkiin muuton ollessa kysymyksessä. Maalaiskuntiin muuttaneet ovat niin muodoin suuremmassa määrässä kuin kaupunkiin muuttaneet vanhempaa väkeä taikka alaikäisiä.

Perhesuhteet. Muuttoliikkeen voimakkuutta arvioitaessa on kiinnitettävä huomiota myös siihen, missä määrin toiselle paikkakunnalle siirtyvät muuttavat yksinään, missä määrin taas perheen muiden jäsenten mukana. Yksinäiset henkilöt samoin kuin perheiden päämiehetkin muodostavat muuttoliikkeen varsinaisen aktiivisen aineksen, kun taas muut seuraavat mukana passiivisesti. Mitä enemmän ensiksi mainittuja muuttovirtaan littyy, sitä suuremman tehon se saa.

Taulukossa 12 on Muuruveden, Nilsiän, Tuusniemen ja Vieremän kunnista muuttaneet jaettu yksinään muuttaneisiin ja perheen muiden jäsenten kanssa muuttaneisiin, joista viimeksi mainittuja tässä lyhyyden vuoksi nimitetään perheessä muuttaneiksi. Perhemuuton on katsottu olevan kysymyksessä myös silloin, kun avioton äiti muuttaa lapsineen, olipa näitä sitten yksi tai useampia. Yksinmuutoiksi taas on laskettu tapaukset, jolloin täysikasvuiset sisarukset yhdessä lähtevät kotikunnastaan, siirtyivätpä he sitten samalle paikkakunnalle tai eri tahoille. 
Taulukko 12. Yksinään ja perheessä muuttaneiden prosentuaalinen osuus muuttaneiden kokonaismäärästä vv. 1921-1944.

$1921-1939$

Muuton määränpää

Kuopion läänin kaupungit 56,4

Helsinki ............ 83,5

Muut kaupungit ........ 55,2

Kaupungit yhteensä ...... 61,2

Naapurikunnat $\ldots \ldots \ldots \ldots .35,2$

Muut maalaiskunnat .... 48,1

Maalaiskunnat yhteensä .. 41,5

Kaikkiaan ........... 46,8

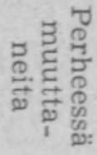

43,6

16,5

44,8

38,8

64,8

51,9

58,5

53,2

$1940-1944$

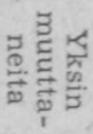

56,9

83,1

78,1

66,1

36,9

47,1

42,7

48,2

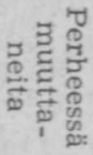

43,1

16,9

21,9

33,9

63,1

52,9

57,3

51,8

Rauhan vuosina muuttaneista oli pyörein luvuin $47 \%$ yksin ja $53 \%$ perheessä muutaneita. Sotavuosina edellisten luku oli yhtä prosenttia suurempi ja jälkimmäisten vastaavasti pienempi. Eri kuntaryhmiin muuttaneiden osalta rauhan ja sodan vuodet eivät tässä suhteessa sanottavammin eroa toisistaan. Ainoan poikkeuksen muodostavat Kuopion läänin ulkopuolella sijaitsevat kaupungit Helsinkiä lukuun ottamatta. Kun niihin muuttaneista vv. $1921-1939$ noin $45 \%$ oli perheessä muuttaneita, vastaava luku sotavuosina oli vain $22 \%$. Vähennys johtuu lähinnä siitä, että monet mainituista kaupungeista sijaitsivat sotatoimialueella, jonne lapsia ei ollut hyvä viedä.

Perheessä muuttaneet muodostavat maalaiskuntiin muuttaneiden enemmistön, joka naapurikuntiin siirtyneiden ryhmässä nousee lähes kahteen kolmasosaan. Kaupunkeihin muuttaneista taas yksinäiset henkilöt muodostivat rauhan aikana kolme viidesosaa ja sotavuosina kaksi kolmasosaa. Helsinkiin muuttaneista heitä on ollut yli $83 \%$. Yleensä yksin muuttaneiden osuus on sitä suurempi, mitä kauemmaksi tapahtuva muutto kulloinkin on kysymyksessä. 
Taulukko 13. Yksinään ja perheessä muuttaneiden jakaantuminen sukupuolen mukaan vv. 1921-1944.

\begin{tabular}{|c|c|c|c|c|c|c|c|c|}
\hline \multirow{4}{*}{$\begin{array}{l}\text { Muuton määränpää } \\
\text { Kuopion läänin kau- } \\
\text { pungit } \quad \ldots \ldots \ldots \ldots \text {. }\end{array}$} & \multicolumn{4}{|c|}{$1921-1939$} & \multicolumn{4}{|c|}{$1940-1944$} \\
\hline & \multicolumn{2}{|c|}{$\begin{array}{c}\text { Yksin } \\
\text { muuttaneet }\end{array}$} & \multicolumn{2}{|c|}{$\begin{array}{c}\text { Perheessä } \\
\text { muuttaneet }\end{array}$} & \multicolumn{2}{|c|}{$\begin{array}{l}\text { Yksin } \\
\text { muuttaneet }\end{array}$} & \multicolumn{2}{|c|}{$\begin{array}{l}\text { Perheessä } \\
\text { muuttaneet }\end{array}$} \\
\hline & Mp. & Np. & Mp. & Np. & Mp. & Np. & Mip. & Np. \\
\hline & 34,6 & 65,4 & 49,9 & 50,1 & 27,2 & 72,8 & 46,2 & 53 \\
\hline Helsinki ... & 24,3 & 75,7 & 44,3 & 55,7 & 25,7 & 74,3 & 52,2 & 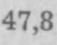 \\
\hline Muut kaupungit & 36,4 & 63,6 & 46,9 & 53,1 & 31,8 & 68,2 & 56,7 & 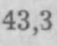 \\
\hline Kaupungit yht. . & 32,3 & 67,7 & 48,6 & 51,4 & 27,9 & 72,1 & 48,1 & 51,9 \\
\hline Naapurikunnat & 29,2 & 70,8 & 49,3 & 50,7 & 24,0 & 76,0 & 48,2 & 51, \\
\hline alaiskunr & 33,7 & 66,3 & 48,9 & 51,1 & 25,8 & 74,2 & 45,4 & 54,6 \\
\hline Maalaiskunnat yht & 31,8 & 68,2 & 49,1 & 50,9 & 25,1 & 74,9 & 46,7 & 80, \\
\hline Kaikkiaan & 32,0 & 68,0 & 49,0 & 51,0 & 26,0 & 74,0 & 46,9 & 53 \\
\hline
\end{tabular}

Perheessä muuttaneet jakaantuvat jotenkin tasan kummankin sukupuolen kesken naispuolisten kuitenkin ollessa enemmistönä. Yksin muuttaneista sensijaan oli rauhan vuosina yli kaksi kolmasosaa, sotavuosina lähes neljä viidesosaa naispuolisia.

Eri kuntaryhmiin muuttaneiden vertailu osoittaa, että Helsinkiin ja muihin Kuopion läänin ulkopuolella sijaitseviin kaupunkeihin muuttaneet perheet olivat rauhan vuosina verraten naisvoittoisia. Monissa tapauksissa niihin muuttavan perheen muodosti yksinäinen äiti tyttärineen. Sotavuosina nämä kaupungit sensijaan olivat siinä määrin vaaranalaisia, että niihin muuttaa nyt ennen kaikkea perheiden miespuoliset jäsenet.

Yksin muuttaneiden joukossa on naisellinen edustus rauhan vuosina vahvin silloin, kun on kysymyksessä Helsinkiin muutto, mutta hyvin runsaslukuisina naiset ovat mukana myös naapurikuntiin ja muihinkin kuntiin tapahtuvassa muuttoliikkeessä. Sotavuosina heidän osuutensa kasvaa kautta linjan, lukuun ottamatta Helsinkiin muuttaneiden ryhmää; jossa se vähän alenee.

Muuttaneiden perheiden suuruudesta ei käytettävissä olevan aineiston perusteella voida tehdä mitään pitemmälle meneviä päätelmiä. Mahdollista näet on, että aineisto eräissä tapauksissa osoittaa perheet liian pieniksi, etenkin silloin, kun perheen- 
huoltaja aluksi yksin siirtyy toiselle paikkakunnalle ja muu perhe seuraa perästä vasta jonkin ajan kuluttua. Taulukossa 13 olevien lukujen perusteella voidaan joka tapauksessa todeta, että kaupunkeihin muuttaneet perheet ovat pienempiä kuin maalaiskuntiin muittaneet ja että pienimmät perheet ovat muuttaneet kauimmaksi, kuten luonnollista onkin. Perheiden keskimääräinen suuruus oli rauhan vuosina $3,7^{\prime}$ henkeä.

Taulukko 13. Vuosina 1921-1939 muuttaneiden perheiden keskimääräinen suuruus.

$\begin{array}{ccc}\text { Muuton määränpää } & \begin{array}{c}\text { Perheessä muut- } \\ \text { taneiden luku }\end{array} & \begin{array}{c}\text { Perheiden } \\ \text { luku }\end{array}\end{array}$

Kuopion läänin kaupungit 1004

Helsinki ............ 122

Muut kaupungit ........ 418

Kaupungit yhteensä ...... 1544

Naapurikunnat ........ 3549

Muut maalaiskunnat .... 2680

Maalaiskunnat yhteensä .. 6229

Kaikki kunnat yhteensä . . 7773

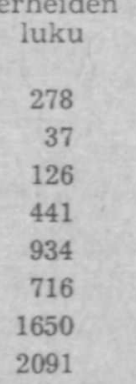

Perheen keskimääräinen jäsenluku

3,6

3,3

3,3

3,5

3,8

3,7

3,8

3,7

Mu ut aneiden a m mat $t$. Tutkimusta varten kerätystä aineistosta muuttaneiden ammattia koskevat tiedot osoittautuivat vähemmän käyttökelpoisiksi. Maamme ammattitilasto on tunnetusti epäluotettavaa, se kun perustuu pääasiallisesti kirkonkirjoihin, joiden ammattia koskevat merkinnät hyvin usein ovat vanhentuneita. Papiston on mahdoton seurata seurakuntalaisten kaikkia ammatinvaihdoksia, joita nykyaikana tapahtuu hyvin ahkeraan. Muuttaneiden luettelot eivät tässä suhteessa ole sẹn luotettavampaa kuin kirkon pääkirjaankaan. Niissä ilmenneistä puutteista mainittakoon etenkin seuraavat:

1. Ammattinimitykset ovat liian ylimalkaisia. Yleisesti esiintyvä nimitys »työmies» tai »työläinen ei ilmoita, saako asianomainen toimeentulonsa maa- tai metsätaloudesta, teollisuudesta vaiko jostakin muusta elinkeinosta. Samoin on laita sellaisten nimitysten kuin »loinen», sitsellinen», »kylänloppu- 
lainen» ja »mäkitupalainen». Myöskään sana »palvelija» ei tarkalleen kuvasta ko. työn laatua.

2. Perheen päähenkilön ammatti tai yhteiskunnallinen asema määrää hyvin usein hänen lapsistaan käytetyn nimityksen, siinäkin tapauksessa, että nämä muuttavat seurakunnasta yksinään ja toimivat eri alalla kuin perheen päämies. Etenkin 1920luvulla suuri osa muuttajista oli vain »loisen poikia», »mäkitupalaisen tyttäriä» jne.

3. Nimityksiä »talollinen», »tilallinen», »pientilallinen» jne. on ilmeisesti käytetty siinä määrin vapaasti, ettei niiden perusteella voi tehdä mitään päätelmiä asianomaisten henkilöiden viljelmien suuruudesta.

4. Eräissä tapauksissa muuttaneet on luettelossa merkitty sen elinkeinon harjoittajiksi, johon he esim. kaupungeissa ovat antautuneet, eikä siis siihen ammattiin kưuluviksi, mikä heillä oli maalta muuton tapahtumishetkellä. Näin on voinut käydä etenkin silloin, kun muuttokirja on hankittu pitemmän ajan kuluttua muutosta.

Nimikkeistö on lisäksi ollut kehitystilassa sikäli, että siinä vuosien mittaan tapahtuu täsmällisentymistä ja eräänlaista »hienostumista». 1920-luvun »mäkitupalaisen tytärtä» tai »loisen tytärtä» näyttää myöhemmin monissa tapauksissa vastaavan nimitys »palvelija», joka sitten uusimpana aikana alkaa väistyä »kotiapulaisen» tai »talousapulaisen» tieltä. Toisaalta aletaan myös käyttää titteliä »neiti», lähinnä varakkaampien perheiden tyttäristä, mitä nimitystä ammattitilaston kannalta on pidettävä haitallisena kasvannaisena.

Aineiston epäluotettavuudesta huolimatta on taulukossa 14 koetettu antaa edes jonkinlainen kuva siitä, mistä väestöpiireistä ko. kunnista asutuskeskuksiin vv. 1921-1944 muuttaneet henkilöt olivat peräisin. Asutuskeskuksiksi on tässä tapauksessa luettu myöskin kauppalat sekä ne kunnat, joissa v. 1940 sijaitsi taajaväkinen yhdyskunta. Ryhmittelyä toimitettaessa on pidetty silmällä virallisen väestötilastomme luokittelua. Sen mukaisesti on maatalousväestä jaettu kolmeen alaryhmään, nim. itsenäiseen maatalousväestöön (virallisen tilastomme ryhmät 
I A 1-6), vuosipalkollisväestöön (ryhmät I A 7-9) ja päiväpalkkalaisväestöön (ryhmät I A 10 a ja b). Muuttaneiden luetteloissa esiintyvät maatalousväestön ammattinimitykset on jaettu mainittujen kolmen ryhmän kesken seuraavasti:

Itsenäinen maatalousväestö: tilanomistajat, tilalliset, talolliset, palstatilalliset, torpparit, pienviljelijät, vuokraajat, lampuodit ja kruununtorpparit.

Vuosipalkollisväestö: tilanhoitajat, voudit, muonamiehet, rengit ja palvelijat.

Päiväpalkkalaiset: mäkitupalaiset, itselliset ja loiset.

Viimeksi mainittuun ryhmään luetuista, so. mäkitupalaisista, itsellisistä ja loisista, osa voi saada toimeentulonsa teollisuudesta tai muista ei-maataloudellisista elinkeinoista, mutta virallisen tilastomme mukaisesti heidät kuitenkin on katsottu lähinnä maatalousväestöön kuuluviksi ${ }^{8}$. Sensijaan sellaiset »työmiehet» ja »työläiset», joiden työn laadusta ei ole saatu tarkempaa selvyyttä, on ollut pakko merkitä luokkaan »työläisiä, päiväpalkkalaisia ilman edellämainittua ammattia», vaikka onkin ilmeistä, että suuri osa heistä oikeastaan kuuluu maataloustyöväestön päiväpalkkalaisten tai vuosipalkollisten ryhmään.

Taulukko 14. Eri ammattiryhmien osuus asutuskeskuksiin muuttaneiden koko luvusta vv. 1921-1944.

\begin{tabular}{|c|c|c|c|c|c|c|}
\hline \multirow{2}{*}{ Ammatti tai elinkeino } & \multirow{2}{*}{$\begin{array}{c}1921- \\
1930\end{array}$} & \multirow{2}{*}{$\begin{array}{c}1951- \\
1940\end{array}$} & \multirow{2}{*}{$\begin{array}{c}1941- \\
1944\end{array}$} & \multicolumn{3}{|c|}{$1921-1944$} \\
\hline & & & & Miesp. & Naisp. & Yht. \\
\hline & $\%$ & $\%$ & $\%$ & $\%$ & $\%$ & $\%$ \\
\hline Maatalous & 54.3 & 52,4 & 53,9 & 39,0 & 62,7 & 53,4 \\
\hline Itsenäinen väestö & 19,8 & 23,9 & 21,7 & 21,0 & 22,6 & 22,0 \\
\hline $\begin{array}{l}\text { Epäitsenäinen väestö } \\
\text { Vuosipalkolliset }\end{array}$ & 8.5 & & & 3 & & 16.6 \\
\hline Päiväpalkkalaiset & 25,2 & & $\begin{array}{r}4,0 \\
3,8\end{array}$ & 14,0 & 13,2 & 13,5 \\
\hline Sivuelinkeinot & 0,8 & 0,9 & 4,4 & 1,7 & 1,1 & 1,3 \\
\hline Teollisuus ja käsity & 5 , & 5,4 & 5,8 & 7,8 & 4,2 & 5,6 \\
\hline Liikenne ja kauppa & 4,4 & 6,3 & 8,1 & 7,8 & 4,4 & 5,7 \\
\hline Julkiset toimet ja vapaat & 6,4 & 5,1 & 9,5 & 7,6 & 5,3 & 6,2 \\
\hline Työläiset ilman edelläm. ammattia & 20,3 & 16,5 & 15,3 & 29,2 & 10,6 & 17,9 \\
\hline 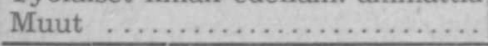 & 8,8 & 14,3 & 7,4 & 8,6 & 12,8 & 11,2 \\
\hline Yhteensä & 100,0 & 100,0 & 100,0 & 100,0 & 100,0 & 100,0 \\
\hline
\end{tabular}


Taulukkoa 14 on kuitenkin syytä tarkastella rinnan seuraavan (15.) taulukon kanssa, joka kymmenvuotistaulustoon perustuen osoittaa, suurenko osan ko. ammatti- ja elinkeinoryhmät muodostivat vv. 1920, 1930 ja 1940 kuntien koko läsnäolevasta väestöstä. Kun näiden tietojen pohjana ovat kirkon pääkirja sekä papiston henkilökohtainen väestöntuntemus, niitä on pidettävä luotettavampina kuin muuttaneiden luetteloista saatu$\mathrm{ja}^{9}$. Vertailun helpottamiseksi viimeksi mainittukin aineisto on taulukossa 14 jaettu vuosijaksoihin 1921-1930, 1931-1940 ja 1941-1944.

Taulukko 15. Läsnäolevan väestön jakaantuminen ammatin ja elinkeinon mukaan vv. 1920, 1930 ja 1940.

Ammatti tai elinkeino

\begin{tabular}{|c|c|c|c|}
\hline Ammatti tai elinkeino & 1920 & 1930 & 1940 \\
\hline & $\%$ & $\%$ & $\%$ \\
\hline Maatalous ........... & 86,4 & 85,7 & 77,8 \\
\hline Itsenäinen väestö .. & 46,2 & 46,8 & 55,5 \\
\hline Vuosipalkollisväestö $\ldots \ldots \ldots \ldots \ldots$ & 3,3 & 6,5 & 4,4 \\
\hline Päiväpalkkalaisväestö & 36,7 & 31,8 & 17,1 \\
\hline Sivuelinkeinot $\ldots \ldots \ldots \ldots \ldots \ldots \ldots$ & 0,2 & 0,6 & 0,8 \\
\hline Teollisuus ja käsityö $\ldots \ldots \ldots \ldots \ldots \ldots$ & 4,0 & 5,9 & 12,6 \\
\hline Liikenne ja kauppa ............... & 1,3 & 2,4 & 2,2 \\
\hline Julkiset toimet ja vapaat ammatit .... & 1,3 & 1,3 & 1,9 \\
\hline $\begin{array}{l}\text { Työläiset ilman edellämainittua am- } \\
\text { mattia } \ldots \ldots \ldots \ldots \ldots \ldots \ldots \ldots \ldots \ldots \ldots \ldots\end{array}$ & 1,1 & 0,7 & 1,6 \\
\hline Muut tai ammatti tuntematon ........ & 5,9 & 4,0 & 3,9 \\
\hline Yhteensä & 100,0 & 100,0 & 100,0 \\
\hline
\end{tabular}

Edellisen taulukon mukaan asutuskeskuksiin vv. 1921-1944 siirtyneistä on $53,4 \%$ ollut maalaisväestöön kuuluvia. Tämä luku on kuitenkin ilmeisesti aivan liian pieni. Kuten edellä jo on huomautettu, melkoinen osa ryhmästä »työläiset ilman edellämainittua ammattia» kuuluu nähtävästi maataloustyöväkeen. Tätä olettamusta tukee se seikka, että taulukon mukaan miehet ovat suhteettoman heikosti edustetut vuosipalkollisten ryhmässä, mutta sitä runsaammin mukana edellä mainitussa työläisten ryhmässä. Mitä viimeiseen ryhmään »muut» tulee, sen enem- 
mistön muodostavat henkilöt, joiden ammattia ei ole muuttaneiden luetteloon merkitty, mutta jotka hekin todennäköisesti suurelta osalta kuuluvat maatalousväestöön.

Mainitut kolme ryhmää, maatalousväestö, »työläiset ilman edellämainittua ammattia» ja »muut», muodostivat vv. $1921-$ 1930 yhteensä $83,4 \%$ ja vv. $1931-1940$ yhteensä $83,2 \%$ asutuskeskuksiin muuttaneiden kokonaismäärästä. Koko väestöstä niiden osuus oli paljon suurempi, nim. v. 192093,4 ja 10 vuotta myöhemmin 90,4\%. Kun kahden viimeksi mainitun ammattiryhmän osuus koko väestöstä (ja todennäköisesti myöskin kunnista muuttaneista) on verraten vaatimaton, voidaan sanoa, että maatalousväestö on osallistunut asutuskeskuksiin suuntautuneeseen muuttoliikkeeseen vähemmässä määrässä kuin mitä sen osuus koko väestöstä edellyttäisi.

Tässä suhteessa sen eri alaryhmien välillä on kuitenkin olemassa melkoista eroavaisuutta. Jos sillä perusteella, että teollinen toiminta ko. kunnissa on verraten vähäistä (vertaa jälempänä s. 129), olettaisimme niiden työläisten, joiden työn laatua ei ole tarkemmin ilmoitettu, edustavan osaksi vuosi-, osaksi päiväpalkkalaisväestöä, saisimme epäitsenäiseen maatalousväestöön kuuluvien muuttajien osuudeksi vv. $1921-1930 \quad 54,0 \%$ ja vv. 1931-1940 44,1 \%. Nämä määrät eivät liene ainakaan liian suuret, sillä osa ammattiryhmään »muut» sisältyvistä kuuluu varmaan epäitsenäiseen väestöön. Mainitut prosenttiluvut ovat suuremmat kuin mikä epäitsenäisen maatalousväestön osuus oli koko väestöstä (v. 192040,0 ja 1930 38,3\%).

Suuriko osa tilattomaan maatalousväestöön kuuluvista muuttajista tulee vuosipalkollis-, suuriko päiväpalkkalaisväestön osalle, sitä on taulukon 14 lukujen perusteella uskallettua mennä sanomaan. Muuttaneiden luetteloissa käytettyjen nimitysten vaihtuminen lienee vaikuttanut sen, että vuosipalkollisten osuus 1930-luvulla voimakkaasti nousee, kun taas päiväpalkkalaisten vastaavasti laskee. Vertailu taulukon 15 lukujen kanssa osoittaa kuitenkin riidattomasti, että ensiksi mainittujen osuus asutuskeskuksiin muuttaneista on ollut ainakin kaksin-kolminkertai- 
nen, ehkäpä suurempikin, verrattuna heidän osuuteensa koko väestöstä.

Tämän päätelmän kanssa ristiriidassa näyttää olevan se seikka, että vuosipalkollisväestö on ko. kunnissa kasvanut vv. 1920-1940 3,3\%:sta 4,4\%:iin, kun taas päiväpalkkalaisväestö on vähentynyt $36,7 \%$ :sta $17,1 \%$ :iin. On kuitenkin muistettava, että ensiksi mainittuun väestöön kuuluu etupäässä nuoria, naimattomia miehiä ja naisia, jotka usein vaihtavat paikkaa ja helposti siirtyvät toisille toimialoille. Heidän tilalleen on jatkuvasti hankittava uutta väkeä, jota saadaan lähinnä päiväpalkkalais- ja pienviljelijäpiireistä. Nämä ryhmät joutuvat siis osallistumaan maalta muuttoon paitsi suoranaisesti myös välillisesti, so. toisten ammattiryhmien ja etenkin vuosipalkollisväestön muodossa. Päiväpalkkalaisten lukua on sanottuina vuosikymmeninä alentanut jossakin määrin myös se seikka, että osa heistä on lähinnä asutustoiminnan ansiosta päässyt viljelemään omaa maata. Itsenäisen maatalousväestön osuus on vv. 1921-1940 lisääntynyt ko. kunnissa 46,2:sta 55,5 \%:iin.

Mitä itsenäisen maatalousväestön edustukseen asutuskeskuksiin muuttaneiden joukossa tulee, se on tuntuvasti pienempi, kuin mitä sen osuus koko väestöstä edellyttäisi. Taulukon 14 mukaan tämä väestö muodosti vv. $1921-1930$ vain 19,8 ja seuraavalla vuosikymmenellä $23,9 \%$ kaikista asutuskeskuksiin muuttaneista. Asian laita ei sanottavammin muutu siitä, yaikka edellyttäisimmekin tätä väestöä jossakin määrin sisältyvän myös mainitun taulukon kahteen vimeiseen ammattiryhmään. Oma viljelmä näyttää näin ollen olevan se side, joka tehokkaammin kuin mikään muu pidättää maatalousväestöä siirtymästä asutuskeskuksiin.

Muista ammattiryhmistä ovat ainakin kaupan ja liikenteen palveluksessa olevat sekä julkisten tointen ja vapaiden ammattien harjoittajat olleet paljon runsaslukuisempina edustettuina asutuskeskuksiin muuttaneiden joukossa kuin koko väestössä. Heidän suhteellinen osuutensa muuttaneista näyttää sitäpaitsi vuosikymmenien kuluessa jatkuvasti kasvaneen. Kauppa-apulaiset, farmaseutit, sairaanhoitajat, opettajat ym. pyrkivät hekin 
yhä lisääntyvässä määrässä siirtymään suuremmille paikkakunnille. Onko asian laita sama myös teollisuus- ja käsityöväestöön nähden, siitä aineistomme ei anna selvää kuvaa. Teollisuusväestön prosenttiluvut taulukossa 14 ovat varsin alhaiset, vv. 1931 -1940 ja 1941-1944 jopa pienemmät kuin mikä heidän osuutensa koko asujaimistosta oli vv. 1930 ja 1940 , mutta juuri tätä väestöä voi sisältyä myös ryhmään »työläisiä ilman edellämainittua ammattia».

Taulukko 16. Naisten prosentuaalinen osuus asutuskeskuksiin muuttaneista eri ammattiryhmissä vv. 1921-1944.

$$
1921-1930 \quad 1931-1940 \quad 1941-1944
$$

\begin{tabular}{|c|c|c|c|}
\hline Maatalous & 62,9 & 77,4 & 77,8 \\
\hline Itsenäinen väestö & 55,7 & 66,7 & 67,6 \\
\hline \multicolumn{4}{|l|}{ Epäitsenäinen väestö } \\
\hline Vuosipalkolliset $\ldots \ldots \ldots \ldots \ldots$ & 93,2 & 95,5 & 92,9 \\
\hline Päiväpalkkalaiset & 59,0 & 61,0 & 64,0 \\
\hline Sivuelinkeinot ....... & 41,2 & 47,8 & 58,6 \\
\hline Teollisuus ja käsityö ... & 50,0 & 41,0 & 50,0 \\
\hline Liikenne ja kauppa .......... & 52,7 & 52,8 & 49,1 \\
\hline Julkiset toimet ja vapaat ammatit .... & 45,9 & 54,3 & 59,7 \\
\hline Työläiset ilman edelläm. ammattia .... & 36,5 & 34,6 & 42,0 \\
\hline \multirow[t]{2}{*}{ Muut $\quad \ldots \ldots \ldots \ldots \ldots \ldots \ldots$} & 65,2 & 71,8 & 75,0 \\
\hline & 55,5 & 64,3 & 66,5 \\
\hline
\end{tabular}

Aikaisempien taulukkojen täydennykseksi esitetään vielä taulukko 16, joka osoittaa naisten prosentuaalisen osuuden muuttaneiden eri ammattiryhmissä. Sen mukaan he ovat koko tutkimuksemme kohteena olevana aikana muodostaneet vuosipalkollisten ryhmästä yli $90 \%$. Tämä korkea luku näyttää osaltaan tukevan sitä edellä esitettyä olettamusta, että miespuoliset vuosipalkolliset ovat »työmiehinä» joutuneet luetuiksi silman edellämainittua ammattia» olevien ryhmään, jossa taas naisia on verraten vähän.

Eräs seikka, jonka taulukko 16 varmasti osoittaa, on se suuri ero, mikä naisten prosentuaaliseen osuuteen nähden on olemas- 
sa asutuskeskukseen muuttaneen maatalousväestön sekä muiden elinkeinoryhmien välillä. Teollisuus- ja käsityöväestöön kuuluvista muttaneista on vähintään puolet, 1930-luvulla enemmänkin, ollut miehiä. Tämä asian laita ei muutu siitä, vaikka katsoisimmekin osan »työläisistä ilman edellämainittua ammattia» kuuluvan teollisuusväestöön, päinvastoin se nähtävästi lisäisi miesten enemmyyttä. Kaupan ja liikenteen sekä julkisten tointen ja vapaiden ammattien ryhmiin kuuluvista muuttajista naiset muodostavat vähäisen enemmistön, mutta se on pientä siihen ylivoimaan nähden, mikä heillä on maatalousväestön ryhmässä.

Aikaisemmin on jo osoitettu, että kaupunkeihin muuttaneet ovat suurimmalta osalta olleet nuoriâ naisia. Taulukko 16 puolestaan osoittaa, että nämä nuoret naiset tulevat ennen kaikkea maatalousväestön piiristä. Heidän joukossaan ovat niin hyvin maanomistajien ja vuokraajien kuin maataloustyöläistenkin tyttäret runsaasti edustettuina. Tämä muuttoliike vetää kyllä mukaansa maatalousväestöön kuuluvia miehiäkin, samoin muihinkin elinkeinoryhmiin kuuluvia, mutta ennen kaikkea »maaltapako» sittenkin on näissä kunnissa naispuolisen maatalousväestön piirissä esiintyvä ilmiö. Maaltamuuton syiden selvittelyssä onkin senvuoksi kiinnitettävä erikoista huomiota maaseudun naisten asemaan ja olosuhteisiin.

\section{Maalta muuton syyt.}

Haastattelujen tulokset. Tutkimusaineistomme keruun yhteydessä pyrittiin, kuten edellä jo on mainittu, selvittelemään myös ko. seurakunnista vuosina 1935-1944 muuttaneiden poislähdön syy. Tämä tehtävä osoittautui melko vaikeaksi. Sellaisia henkilöitä, jotka olivat oleskelleet paikkakunnalla vain lyhyen aikaa, ei ehkä enää muistettu, eikä paikkakunnalla syntyneidenkään lähdön syistä oltu aina selvillä. Saadut tiedot saattoivat senvuoksi olla keskenään ristiriitaisia. Aineiston kerääjät puolestaan suhtautuivat tehtäväänsä eri tavoilla. Toisen hy- 
väksyessä sellaiset ylimalkaiset vastaukset kuin »lähti paremmille ansioille» tai »ei viihtynyt maaseudulla» toinen pyrki ottamaan tarkemman selon asianomaisten olosuhteista ja myöhemmistäkin vaiheista. Aineisto muodostui täten laadultaan hyvir. vaihtelevaksi, eikä sen esittäminen numeroiden avulla senvuoksi ole tarkoituksenmukaista.

Yleisvaikutelmana aineistosta voidaan sanoa, että asutuskeskuksiin muuttaneet miehet ovat yleensä olleet tyytymättömiä työpalkkaansa, naiset taas työnsä laatuun. Tavallisin selitys miehen osalta oli: »lähti parempia työmahdollisuuksia etsimään», »piti palkkaa huonona» tai »ei ollut työtä tarpeeksi». Naiset taas ovat tavallisimmin valittaneet työn paljoutta ja sen raskautta, toiset myös sen epäsiisteyttä. Heidän kohdallaan esiintyy usein myös maininta »maalla liian hiljaista» tai »ei huvittelumahdollisuuksia maalla». Sekä naisten että miesten poismuuttoon on vaikuttanut se, että »maatyö ei miellytä».

Mainitunlaiset vastaukset eivät kuitenkaan kykene tyydyttävästi selittämään »maaltapaon» ongelmaa. Ei voida pitää riittävänä selityksenä sitä, että palkat kunnassa ovat huonot tai että elämä siellä ei ole viihtyisää, vaan on pyrittävä selvittämään, miksi palkat ovat alhaiset ja olosuhteet muutenkin epätyydyttävät. Seuraavassa esityksessä koetamme valaista tätä kysymystä osaksi virallisen tilaston antamien tietojen, osaksi aineistomme kerääjien huomioiden pohjalta.

Ei-maataloudellisten elinkeinojen edustama työvoiman kysyntä. Vuonna 1930 noin $86 \%$ tutkimuksemme kohdekuntien läsnäolevasta väestöstä sai toimeentulonsa maataloudesta, kuten taulukko 15 osoittaa. Maatalousväestön osuus oli suurin Nilsiässä $(91,4 \%$ ja alhaisin Tuusniemellä $(81,2 \%)$, mutta viimeksi mainittukin kunta oli tässä suhteessa sentään yläpuolella sekä Kuopion läänin että koko maan maaseudun heskiarvojen $(78,7 \text { ja } 72,7 \%)^{10}$.

Vuoteen 1940 mennessä maatalousväestön osuus väheni Muuruvedellä ja Vieremällä alle $70 \%: n(69,8$ ja $69,9 \%)$, kun se taas Nilsiässä ja Tuusniemellä edelleenkin oli varsin korkea $(84,0$ 
ja $82,6 \%$ ). Samanaikaisesti teollisuus- ja käsityöväestön osuus, joka v. 1930 vaihteli näissä kunnissa 4,4\%:sta (Nilsiässä) 8,5 \%:iin (Vieremällä), nousi vuoteen 1940 mennessä Muuruvedellä 17,6:een ja Vieremällä 21,2\%:iin². Tällä perusteella voisi olettaa, että näihin kuntiin olisi 1930-luvulla syntynyt huomattavia teollisuuslaitoksia. Näin ei kuitenkaan ole asian laita. Teollisuustilaston mukaan Vieremällä ei v. 1940 ollut yhtään teollisuuslaitosta. Muuruvedellä oli yksi, mutta senkin palveluksessa oli ainoastaan 6 työntekijää ${ }^{11}$.

Pääasiallisimpana syynä Muuruveden ja Vieremän teollisuusväestön lisääntymiseen vv. 1931-1940 ovat metsä- ja uittotyöläiset. He muodostivat v. 1940 edellisessä kunnassa 80,2 ja jälkimmäisessä $96,2 \%$ koko teollisuusväestöstä, johon kymmenvuotistaulustomme ammattitilasto heidät lukee. Vuonna 1930 heidän lukunsa silloin vallinneen pulakauden johdosta jäi nähtävästi tavallista alhaisemmaksi, mutta kymmenen vuotta myöhemmin metsätalouden työtilanne oli aivan toinen. Se seikka, että metsä- ja uittotyöläisiä tällöin oli Nilsiässä vain $16,7 \%$ koko teollisuusväestöstä vastaavan luvun ollessa Tuusniemellä $61,6 \%$, ei merkitse sitä, että metsätalouden merkitys Nilsiässä olisi vähäisempi kuin muissa ko. kunnissa, vaan johtuu todennäköisesti siitä, että näihin töihin osallistuvat on Nilsiän seurakunnassa suuremmassa määrässä kuin muissa luețtu maatalousväestöön kuuluviksi. Siihen he paremmin kuuluvatkin, sillä suurin osa heistä on oikeastaan maanviljelijöitä taikka maataloustyöläisiä, joille metsä- ja uittotyöt tarjoavat tervetullutta lisäansiota ${ }^{12}$.

Varsinaista teollisuustoimintaa Muuruvedellä ja Vieremällä ei ole, jos jätämme vähäiset sahat, myllyt, meijerit ja sähkölaitokset huomioon ottamatta. Sanottavia mahdollisuuksiakaan suuremmille teollisuuslaitoksille ei ole etenkään Muuruvedellä, jonka kulkuyhteydet ovat huonot ja jossa tarpeellista vesivoimaa ja raaka-ainetta, metsiä lukuun ottamatta, ei ole saatavissa.

Tuusniemen kallioperustaan sensijaan sisältyy useita arvokkaita kivennäisiä. Ennen kaikkea on mainittava asbestikivi, 
jota on tavattu kaikkiaan noin 20 eri paikassa ympäri pitäjää. Tärkeimmät ja teknillisesti käyttökelpoisimmat näistä esiintymistä ovat Paakinniemellä, Ohtaansalmen länsipuolella, jossa toimii Suomen Mineraali Oy:n asbestikaivos ja asbestikuitutehdas. Muista pitäjässä tavattavista kivennäisistä mainittakoon vuolukivi ja grafiitti. Yleensä nämä mineraalit esiintyvät kuitenkin siksi vähäisillä aloilla, että tehdasmainen vuorityö ei niiden perusteella ole osoittautunut kannattavaksi, asbestia lukuun ottamatta.

Nilsiä on varhaisista ajoista ollut tunnettu järvimalmivaroistaan, joihin aikoinaan perustui sangen huomattava rautateollisuus. Kun malminnosto tapahtuu pääasiallisesti käsivoimin, tulee se suhteellisen kalliiksi ja on senvuoksi nykyään menettänyt merkityksensä vuorimalmin vallattua markkinat. Samoin on yleensä käynyt myös sille kiviteollisuudelle, jota Nilsiässä käsityön muodossa on aikaisemmin paljon harjoitettu ja jonka tuotteille, myllyn- ja tahkokiville, pitäjän kallioperä tarjoaa sopivat ainekset ${ }^{13}$.

Nykyään on Nilsiän tärkeimpänä teollisen toiminnan lajina kvartsiitin louhinta. 1930-luvulla oli valkoisen kvartsiittihiekan tuotanto sangen huomattavaa, mutta sota-aikana se joutui lamaan. Valkeiskylässä toimineessa Silika Oy:n hiekkakaivoksessa työt olivat v, 1945 edelleenkin pysähdyksissä, ja Sampo Oy:n työmaa Kinahminkylässä vietti hiljaiseloa. Sen sijaan Rudus Oy:n kaivoksilla olivat työt ripeässä käynnissä. Yhtiön toimesta louhitaan Reittiöstä ja Lasikalliosta vuosittain n. 12.000 tonnia kvartsiittia. Jauhettu kvartsiitti kuljetetaan autoilla Lapinlahden asemalle, mistä se sitten viedään raaka-aineeksi erilaisiin tehtaisiin ${ }^{14}$. Kuljetusvaikeudet rajoittavat kuitenkin näiden kvartsiittiesiintymien laajempaa hyväksikäyttöä.

Kaikissa ko. kunnissa on tietysti myös eri alojen käsityöläisiä, varsinkin suutareita, metsä- ja uittotyöläiset kun tarvitsevat runsaasti jalkineita. Ns. rajasuutarien ohella on etenkin Nilsiässä myös lapikkaantekijöitä, joiden valmisteita normaalisina aikoina on viety runsaasti Kuopioon ja edemmäksikin. Muuruvedellä mainitaan aikaisemmin olleen vaattureita ja ompelijoita 
yli oman tarpeen, minkä vuoksi useat heistä lähtivät kaupunkeihin parempia elinmahdollisuuksia etsimään. Syynä tähän oli lähinnä se, että ennen sotia maaseudullakin ruvettiin yhä enemmän ostamaan vaatteet valmiina kaupoista. Kun sitten sotaaikana jouduttiin jälleen turvautumaan omista kankaista valmistettuihin pukuihin, vaatturien ja ompelijain työ lisääntyi siinä määrin, että heistä nykyään on puutetta.

Käsiteollisuutta on harjoitettu etenkin Nilsiässä, missä on yleisesti valmistettu omassa taloudessa tarvittavat kapineet. Myytäviksi naiset ovat kutoneet puuvillakankaita, huiveja ym. ja miehet valmistaneet $\mathrm{mm}$. hyviksi tunnettuja ajorekiä. Muuruvedellä on tehty tuohitöitä. Tehdastuotteitten halpuus ja laadun paremmuus ovat kuitenkin yhä enemmän supistaneet kotiteollisuuden piiriä ja vähentäneet sen valmisteiden menekkiä. Kun kotiteollisuuden harjoittajien palkat tämän johdosta ovat käyneet varsin alhaisiksi, he ovat menettäneet innostuksensa asiaan, mistä johtuen taas ammattitaito on alentunut ja työntekijäin luku vähentynyt.

Kaupalla ja liikenteellä on näiden kuntien työmarkkinoille varsin vähäinen merkitys. Niiden osalle tuli Nilsiässä v. 1940 yhteensä 2,5\% läsnäolevasta väestöstä, muissa kunnissa vieläkin vähemmän.

Päädymme siis siihen tulokseen, että mikäli näiden kuntien väestö syystä tai toisesta joutuu jättämään pääelinkeinonsa maatalouden, sillä on omalla paikkakunnalla tarjona työtilaisuuksia pääasiallisesti vain metsä- ja uittotöissä, Nilsiässä ja Tuusniemellä jossakin määrin myöskin vuoriteollisuudessa. Näilläkin aloilla suhdannevaihtelut ilmenevät herkästi, jota paitsi ne tarjoavat ansiomahdollisuuksia etupäässä vain miehille. Tämä asiain laita on yhtenä selityksenä siihen, miksi kunnista muuttaneiden valtaosa on naisia ja miksi Muruveden muuttotappio on ollut suurempi kuin esim. Tuusniemen ja Nilsiän.

Työnsaantimahdollisuudet maataloudessa. Viljelty pelto-ala muodosti v. 1943 Muuruvedellä $13,3 \%$ koko maa-alasta vastaavan luvun ollessa Nilsiässä 9,7 , Tuusniemellä 7,7 ja Vieremällä $4,7 \%$. Kun peltoalan osuus Kuopion läänin 
maalaiskunnissa oli keskimäärin $6,1 \%$, tutkimuksemme kohdekunnista ainoastaan Vieremä jäi läänin keskiarvon alapuolelle, kun taas Muuruvesi ylitti sen sataprosenttisesti ${ }^{15}$. I

Viljelmien suuruus tai paremminkin pienuus ilmenee taulukosta 17 , jossa ne on peltoalansa perusteella jaettu viiteen suuruusluokkaan. Viittä peltohehtaaria pienempiä viljelmiä on pidettävä kääpiöviljelminä, jotka eivät yleensä kykene antamaan viljelijälle ja hänen perheelleen riittävää toimeentuloa. Samaa voidaan oikeastaan sanoa myös pienimmistä $5-10$ peltohehtaarin ryhmään kuuluvista viljelmistä, so. varsinaisista pienviljelmistä ${ }^{16}$. Kymmentä peltohehtaaria suuremmista viljelmistä oli Muuruvedellä vain kahdessa, muissa kunnissa kussakin yhdessä ja Kuopion läänin maaseudulla yhteensä 114:ssä peltoa yli 50 ha.

Taulukko 17. Viljelmät peltoalansa suuruuden mukaan v. $1941 .^{x i}$

\begin{tabular}{|c|c|c|c|c|c|c|c|c|c|c|c|c|}
\hline \multirow{3}{*}{ Alue } & \multicolumn{12}{|c|}{ Viljelmien luku, joiden peltoala oli, ha: } \\
\hline & \multicolumn{2}{|c|}{-0.50} & \multicolumn{2}{|c|}{$0,50-2$} & \multicolumn{2}{|c|}{$2-5$} & \multicolumn{2}{|c|}{$5-10$} & \multicolumn{2}{|l|}{10} & \multicolumn{2}{|c|}{ Yhteensä } \\
\hline & Luku & $0 \%$ & Luku & $1 \%$ & Laku & $\%$ & Luku & $\%$ & Luku & $\%$ & Luku & $0 / 0$ \\
\hline Mut & 48 & 9.0 & 104 & 19.5 & 122 & 22.9 & 131 & 24,6 & 128 & 24.0 & 533 & 100. \\
\hline Nils! & 187 & 15,3 & 245 & 20,1 & 319 & 26,2 & 274 & 22,5 & 194 & 15,9 & 1219 & 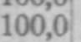 \\
\hline Tuusniemi & 96 & 10,9 & 151 & 17,1 & 291 & 32,9 & 221 & 25,0 & 125 & 14,1 & 884 & 100 \\
\hline Vieremä. : & 129 & 16,7 & 223 & 28,9 & 162 & 21,0 & 130 & 16,8 & 128 & 16,6 & 772 & 100 \\
\hline maz & 7.834 & 17,3 & 21 & 2 & 11.84 & 6 & 8.737 & 19,3 & 6.707 & & 45.3 & 00 \\
\hline
\end{tabular}

Vieremällä kääpiöviljelmät muodostivat kaksi kolmasosaa $(66,6 \%)$ viljelmien koko luvusta eli vähän enemmän kuin Kuopion läänin maaseudulla keskimäärin $(65,9 \%$ ). Paljon alle keskiarvon eivät jääneet Nilsiä ja Tuusniemikään, sillä vastaavat suhdeluvut olivat niiden osalta 61,6 ja $60,9 \%$. Muuruvesi sensijaan on aivan omaa luokkaansa, sillä siellä kääpiöviljelmiä oli vain vähän yli puolet kaikista $(51,4 \%)$, kun taas 10 peltohehtaaria suurempia viljelmiä siellä oli tuntuvasti enemmän kuin muissa kunnissa. 
Muuruveden erikoisasema ilmenee myöskin taulukosta 18 , joka osoittaa viljelmien keskimääräisen suuruuden vv. 1920, 1929 ja 1941. Laskelmissa on otettu huomioon vain peltoalaltaan puolta hehtaaria suuremmat viljelmät.

Taulukko 18. Peltoalaltaan puolta hehtaaria suurempien viljelmien keskimääräinen suuruus (peltohehtaaria) vv. 1920,1929 ja $1941^{18}$.

$\begin{array}{cccccc}\text { Vuosi } & \text { Muuruvesi } & \text { Nilsiä } & \text { Tuusniemi } & \text { Vieremä } & \begin{array}{c}\text { Kuopion } \\ \text { läanin } \\ \text { maaseutu }\end{array} \\ 1920 & 6,7 & 4,5 & 5,0 & - & 5,1 \\ 1929 & 7,6 & 4,9 & 5,3 & 5,4 & 5,5 \\ 1941 & 8,2 & 6,3 & 5,9 & 6,4 & 6,1 \\ & & & & & \text {. }\end{array}$

Sekä vuosina 1920 että 1929 viljelmien keskimääräinen peltoala oli Muuruvedellä tuntuvasti suurempi kuin Kuopion läänin maaseudulla yleensä. Muut ko. kunnat jäivät vielä vuonna 1929 läänin keskiarvon alapuolelle, mutta v. 1941 Nilsiä ja Vieremä jo ylittivät sen jääden silti edelleenkin paljon jälkeen Muuruvedestä.

Viljelmiensä laajuuden puolesta Muuruvesi on siis lähempänä suurviljelmämuotoa kuin muut tutkimuksemme kohdekunnat. Että muuttoliike on juuri siellä ollut vilkkainta ja muuttotappio suurin, ei ilmeisestikään ole mikää̀n sattuma. Ulkomaisissakin muuttoliiketutkimuksissa on näet todettu muuttotappion kasvavan viljelmien keskimääräisen peltoalan suurentuessa ${ }^{19}$. Syynä tähän on nähtävästi maataloustyöväestön suhteellinen runsaus, sen ahkerat paikanvaihdokset ja sen joukkosiirtyminen toisille paikkakunnille. Tähän kysymykseen palaamme kuitenkin tarkemmin myöhemmin (ss. 136-137).

Jo taulukosta 18 selviää, että viljelmien luku ei ole lisääntynyt tutkimuksemme kohdekunnissa yhtä nopeasti kuin Kuopion läänin maaseudulla yleensä. Selvemmin vielä tämä näkyy taulukosta 19, jossa vuosien 1920 ja 1941 lukuja on verrattu toisiinsa. 
Taulukko 19. Peltoalaltaan puolta hehtaaria suurempien viljelmien luvun ja peltoalan lisäys vv. 1920-1941.

\begin{tabular}{|c|c|c|c|c|c|c|}
\hline \multirow[t]{2}{*}{ Alue } & \multicolumn{3}{|c|}{ Peltoala (ha) } & \multicolumn{3}{|c|}{ Viljelmien luku } \\
\hline & 1920 & 1941 & Lisäys $(\%)$ & 1920 & 1941 & Lisäys $(\% / 0)$ \\
\hline Muuruvesi & 3.007 & 3.963 & 31,8 & 447 & 485 & 8,5 \\
\hline Nilsiä & 3.725 & 6.462 & 73,5 & 836 & 1.032 & 23,4 \\
\hline Tuusniemi .... & 3.521 & 4.659 & 32,3 & 704 & 788 & 11,9 \\
\hline Vieremä ... & 3.065 * & 4.104 & 33,9 & 564 * & 643 & 14,0 \\
\hline & & & & & & \\
\hline maaseutu & 42.773 & 229.901 & 61,0 & 7.733 & 37.501 & 35,2 \\
\hline
\end{tabular}

Sekä viljelmien luku että peltoala ovat lisääntyneet vähimmin Muuruvedellä ja Tuusniemellä, ja myöskin Vieremä jää paljon alapuolelle läänin keskiarvon. Nilsiässä peltoalan lisäys on ollut keskimääräistä suurempi, viljelmien lisäys sitä pienempi.

Viljelmien suhteellisen vähäiseen lisääntymiseen ko. kunnissa ei ole ollut syynä se, että tilattomalta väestöltä puuttuisi halua päästä itsenäisen viljelijän asemaan. Päinvastoin »maan nälkä» on niissä kaikkialla selvästi havaittavissa. Esteenä sen tyydyttämiselle on kuitenkin viljelyskelpoisen maan niukkuus. Kuten kuntien esittelyssä jo osoitettiin (s. 103), niiden pinnanmuodostus ei tarjoa maanviljelykselle erikoisempia edellytyksiä, kun hedelmällisiä savikoita on harvassa. Niiden puutteessa on ollut pelloksi raivattava vähemmän edullisia hiekka-, hiesuja hietamaita, jotka vuoden 1941 maatalouslaskennan mukaan muodostivat Tuusniemellä suunnilleen puolet $(49 \%)$, muissa ko. kunnissa $26-28 \%$ koko peltoalasta ${ }^{20}$. Uutisraivaus vaatii sitä paitsi siksi paljon työtä ja kustannuksia, että siihen on vain harvoilla mahdollisuuksia.

Vanhoista viljelmistä taas ei liikene sanottavia muille jaettavaksi. Kuten taulukon 17 luvut osoittavat, Muuruveden viljelmistä oli v. 1941 yli kolme neljäsosaa 10 peltohehtaaria pienempiä. Muissa kunnissa vastaava luku oli vielä paljon suurempi: Nilsiässä 84,1 , Tuusniemellä 85,9 ja Vieremällä $83,4 \%$.

* Vúonna 1929. 
Suurin osa viljelmistä on siis siksi pieniä, että ne eivät voi antaa riittävää toimeentuloa edes viljelijän omalle perheelle saatikka sitten muille. Suurempienkaan tilojen omistajat eivät halua kannattavuus- ym. syistä myydä tai vuokrata maataan, ei etenkään silloin, kun heillä on suuri perhe, kuten tavallisesti on näillä seuduilla asian laita.

Viimeksi mainituista seikoista johtuu, että etenkin pienviljelijäin lasten on työkykyiseen ikään ehdittyään lähdettävä vieraan palvelukseen. Tällöin kotiseudulle jääminen merkitsee heille yleensä sosiaalisen arvon alenemista. Useimpien heistä on näet tyydyttävä »rengin» tai »piian» asemaan, mikä itsenäisen väestön lapsista saattaa omalla kotiseudulla tuntua kiusalliselta. Moni muuttaakin senvuoksi saman tien vähän pitemmälle.

Sitä paitsi viljelijöiden mahdollisuudet palkata itselleen pysyvää työvoimaa ovat rajoitetut. He koettavat tulla toimeen mahdollisimman vähillä vuosipalkollisilla ja hankkivat sitten tilapäistä työvoimaa avuksi kesäkautena, jolloin työtä on enemmän. Epäitsenäinen väestö puolestaan on haluton jäämään päiväpalkkalaisen epävarmaan asemaan, joka takaa ansion saannin vain kiireisimpänä työaikana. Senvuoksi se pyrkii siirtymään sellaisille paikkakunnille, missä työn kysyntä on suurempi ja pysyvämpi.

Tämä kehityksen kulku ilmenee taulukosta 20 , joka osoittaa, montako maatalousväestöön ja sen eri alaryhmiin kuuluvaa henkilöä näissä kunnissa oli 1.000:tta peltohehtaaria kohden vv. 1920,1930 ja 1940.

Vuonna 1920 maatalousväestöä oli túhatta peltohehtaaria kohden Kuopion läänissä enemmän kuin missään muussa läänissämme ${ }^{21}$. Tutkimuksemme kohdekunnissa tämä väestönpaine oli Nilsiässä ja Tuusniemellä vielä suurempi kuin läänissä keskimäärin, ja samoin näyttää asian laita olleen myöskin Vieremällä, vaikka sen osalta erikseen ei olekaan tietoja saatavissa v:lta 1920 . Kymmenen vuotta myöhemmin Tuusniemi oli jo melkein saavuttanut muun läänin tason, kun taas paine Nilsiässä ja Vieremällä oli edelleenkin suuri. V. 1940 tilanne oli 
Taulukko 20. Maatalousväestö 1000 peltohehtaaria kohden vv. $1920-1940^{\circ}$.

\begin{tabular}{|c|c|c|c|c|c|}
\hline Kunta & Vuosi & $\begin{array}{l}\text { Tilallis- } \\
\text { väestöä }\end{array}$ & $\begin{array}{l}\text { Vuosipal- } \\
\text { kollisväestöä }\end{array}$ & $\begin{array}{l}\text { Päiväpalkka- } \\
\text { laisväestöä }\end{array}$ & Yhteensă \\
\hline \multirow[t]{3}{*}{ Muuruvesi } & 1920 & 563 & 67 & 878 & 1508 \\
\hline & 1930 & 584 & 69 & 376 & 1029 \\
\hline & 1940 & 541 & 109 & 70 & 720 \\
\hline \multirow[t]{3}{*}{ Nilsiä } & 1920 & 1165 & 68 & 717 & 1950 \\
\hline & 1930 & 1016 & 137 & 700 & 1853 \\
\hline & 1940 & 752 & 23 & 276 & 1051 \\
\hline \multirow[t]{3}{*}{ Tuusniemi } & 1920 & 1105 & 71 & 729 & 1905 \\
\hline & 1930 & 730 & 173 & 574 & 1477 \\
\hline & 1940 & 763 & 35 & 326 & 1124 \\
\hline \multirow[t]{2}{*}{ Vieremä } & 1930 & 996 & 72 & 596 & 1664 \\
\hline & 1940 & 795 & 85 & 163 & 1043 \\
\hline \multirow[t]{3}{*}{ Kuopion lääni } & 1920 & 1044 & 73 & 687 & 1804 \\
\hline & 1930 & 960 & 66 & 423 & 1449 \\
\hline & 1940 & 756 & 62 & 243 & 1061 \\
\hline
\end{tabular}

muissa kunnissa edullisempi kuin läänissä yleensä paitsi Tuusniemellä, jossa paine edelleenkin oli keskimääräistä korkeampi. Edullisimmassa asemassa on koko ajan ollut Muuruvesi, jossa jo v. 1920 maatalousväestöä oli suhteellisen vähän, mutta jossa sen aleneminen silti on tapahtunut nopeammin kuin muualla.

Selityksen tähän erilaisuuteen saamme tarkastellessamme maatalousväestön eri alaryhmien kehitystä. Ensinnäkin on pantava merkille, että sekä tilallis_ että päiväpalkkalaisväestöä oli v. 1920 Nilsiässä ja Tuusniemellä sekä todennäköisesti myöskin Vieremällä suhteellisesti paljon enemmän kuin läänissä yleensä. Muuruvesi poikkesi muista kunnista kahdessa tärkeässä kohdassa: toisaalta itsenäisen väestön luku 1000 peltohehtaaria kohden oli siellä erikoisen pieni, toisaalta päiväpalkkalaisväestöä oli siellä suhteellisesti enemmän kuin missään muussa kunnassa. Voidaan siis sanoa, että yhteiskunnalliset vastakohdat olivat 1920 -luvun alussa Muuruvedellä suuremmat kuin muissa kunnissa ja Kuopion läänin maaseudulla yleensä. 
Tässä suhteessa on vv. 1921-1940 tapahtunut huomattavaa olojen tervehtymistä. Tilallisväestön suhteellinen määrä ei ole tänä ajanjaksona alentunut Muuruvedellä lainkaan samalla nopeudella kuin muissa kunnissa, mutta päiväpalkkalaisväestön väheneminen sen sijaan on tapahtunut siellä vauhdilla, jolle vain Vieremän vastaavat luvut vuosilta 1930 ja 1940 vetävät vertoja. Näyttåả siltä, että päiväpalkkalaisväestön nopea aleneminen näissä kunnissa olisi pakottanut entistä enemmän turvautumaan pysyvästi palkattuun työväkeen, koska vuosipalkollisväestön suhtecllinen määrä osoittaa niissä jatkuvaa nousua. Nilsiässä ja Tuusniemellä vuosipalkollisten suhteellinen määrä sensijaan on v. 1940 alhaisempi kuin v. 1920. Että se v. 1930 on näissä kunnissa poikkeuksellisen suuri, voitaneen viedä osaksi tilaston epäluotettavuuden tilille, mutta osaksi se voi johtua myös silloisesta pulakaudesta, joka mahdollisesti sai maataloustyöläiset entistä enemmän pyrkimään vakinaiseen palvelukseen.

Eräänä oleellisimpana syynä tutkimuksemme kohdekuntien ja etenkin Muuruveden suureen muuttotappioon vv. 1921-1940 on siis nähtävästi ollut maatalousväestön ja nimenomaan päiväpalkkalaisväestön peltoalaan nähden suuri lukumäärä, joka on näissä kunnissa ollut paljon tuntuvampi kuin läänissä keskimäärin. Missä määrin maatalouden ratsionalisointi on tätä muuttoliikettä jouduttanut, sitä on vaikea sanoa. Maatalouslaskentojen mukaan tavallisimpien maatalouskoneiden luku kasvoi vv. $1929-1941$ Muuruvedellä $57 \%$ :lla, Vieremällä 64 , Nilsiässä 102 ja Tuusniemellä $146 \%$ :lla, jota paitsi Muuruvedelle hankittiin 3 ja Vieremälle 7 traktoria. Tämän johdosta työvoiman tarve on maataloudessa tietysti melkoisesti pienentynyt, mutta tämä koneellistuminenhan voi yhtä hyvin olla maataloudesta paon seuraus kuin sen syykin.

Ilmeistä on, että näiden kuntien kärsimät muuttotappiot ovat ratkaisevalla tavalla vaikuttaneet niiden työmarkkinoihin. Aikaisemmin vallinneen työvoiman runsauden mainitaan hävinneen Muuruvedellä jo v:n 1935 paikkeilla. Pari kolme vuotta ennen sotaa alkoi siellä samoin kuin Nilsiässäkin ilmetä työ- 
voiman puutetta, mikä sitten sodan aikana ja sen jälkeen kehittyi aivan huutavaksi. Nilsiästä esim. kerrotaan, että maatalouteen oli siellä kesällä 1945 miltei mahdoton saada työvoimaa, varsinkaan naispuolista.

Ma a taloustyöväen palkat. Yleinen käsitys on, että niin hyvin nimelliset kuin reaalipalkatkiq ovat maataloudessa alhaisemmat kuin teollisuudessa. Tarkkojen vertailujen teko tässä suhteessa on kuitenkin vaikeata senvuoksi, että maataloudessa on käytännössä monia eri palkkaustapoja ja että teollisuustyöväen palkoista ei pitemmiltä ajanjaksoilta ole saatavissä tarkoituksenmukaista tilastoa.

Palkkaneuvoston v. 1942 asettama toimikunta on kuitenkin kóettanut valaista kehitystä vuosien $1919-1939$ osalta. Sen laskelmat osoittavat, että mikäli omaruokaisten miesten vuosipalkat antavat oikean kuvan maataloustyöväen palkkatason kehityksestä, reaalipalkat olivat maataloudessa 1920-luvun alussa 5-10\% korkeammat kuin v. 1914. Tällä tasolla ne sitten pysyivät aina v:een 1930 asti, mutta vuosina $1931-1932$ ne alenivat jyrkästi, jopa yli $10 \%$ alle vuoden 1914 tason. Vuodesta 1933 maatalouden reaalipalkat alkavat jälleen nousta, ja etenkin vv. 1936-1937 nousu oli huomattavan jyrkkä.

Verrattuna teollisuudessa maksettuihin palkkoihin, joista toimikunnan teollisuustilaston perusteella laskema kutakin työntekijää kohden tuleva keskimääräinen ansio tosin antaa epävarman kuvan, maataloustyöläisten reaalipalkka oli aluksi v:n 1914 vastaavaan arvoon verrattuna korkeampi, mutta jo v. 1925 teollisuustyöntekijäin reaalipalkkaindeksi sivuutti maataloustyöntekijäin indeksin pysyen sitten tämän yläpuolella aina ko. ajanjakson loppuun asti.

Maatalouspalkkojen jyrkän nousun vv. 1936-1938 toimikunta katsoo johtuneen siitä, että pako maataloudesta aiheutti kiristymistä maatalouden työmarkkinoilla. \On arvioitu, että 1930-luvun loppupuoliskolla työkykyinen maataloustyöväen määrä olisi pienentynyt vähintään 200.000 henkilöllä», lausuu toimikunta. 22 
Samantapaisiin tuloksiin päätyy myös tohtori Klaus Waris kuluttajien tuloja vv. 1926-1938 koskevassa tutkimuksesssaan. Hänen mielestään taloudenpito viljelmillä oli ennen vuonna 1928 alkanutta maatalouspulaa verraten ekstensiivistä ja työvoimareservi runsas. Pulavuosina työttömät maataloustyöläiset pyrkivät siirtymään muille aloille, sillä seurauksella, että maataloudessa jo 1936 alkoi esiintyä työvoimapulaa. 1930-luvun lopulla tapahtunut maatalouspalkkojen paraneminen ei näytä johtuneen itse maataloudesta, vaan yhä vähenevästä maataloustyövoiman tarjonnasta, ts. väestön elinkeinorakenteen muuttumisesta. ${ }^{23}$

Palkkatilaston tarkastelu osoittaa kuitenkin, ettei ole olemassa eroa vain maatalouden ja teollisuuden palkkojen välillä, vaan myöskin maatalouden palkkatasossa maan eri osissa. Mainittu palkkatoimikunta on esittänyt $\mathrm{mm}$. tiedot maataloustyöväestön keskimääräisistä palkoista eri lääneissä 5-vuotiskausilta $1920-24,1925-29,1930-34$ ja $1935-39$. Luvut osoittavat, että kolmena ensiksi mainittuna ajanjaksona ko. palkat ovat olleet Kuopion läänissä alhaisemmat kuin maassamme keskimäärin, omaruokaisten hevosmiesten talvisia päiväpalkkoja lukuun ottamatta.

Ajanjaksona 1935-1939 tilanne on kuitenkin toinen. Silloin ovat omaruokaisten hevosmiesten talvipalkkojen ohella myöskin heidän kesäpäiväpalkkansa samoin kuin talonruokaisten hevosmiesten talvipalkat sekä talon tai omassa ruoassa olevien vuosipalkkaisten miesten palkat Kuopion läänissä korkeammat kuin maassa keskimäärin.

Edellämainittujen keskiarvojen lisäksi, jotka perustuvat maataloushallituksen palkkatilastoon, palkkatoimikunta on esittänyt keskimääräiset luvut vuosilta 1935 -1939 myöskin sosiaaliministeriön sosiaalisen tutkimustoimiston julkaisemasta maatalouspalkkatilastosta, joka v:sta 1935 alkaen perustuu entistä laajempaan alkuaineistoon. Sen mukaan päiväläisten keskipalkat olivat kesäisin niin hyvin omassa kuin talon ruoassa olevien miesten että naisten osalta Kuopion läänissä suuremmat kuin maassa keskimäärin. ${ }^{24}$ 
Tämä kaikki viittaa siihen, että maataloustyöväen palkat ovat 1930-luvun jälkipuoliskolla nousseet Kuopion läänissä vielä enemmän kuin muualla maassamme, mikä ilmeisesti on katsottava väestön runsaasta poismuutosta johtuneeksi. Ja syynä tähän poismuuttoon on - työtilaisuuksien puutteen ohella ollut se seikka, että maataloustyöväestön palkat Kuopion läänissä ovat olleet alhaisemmat toisaalta teollisuudessa ym. elinkeinoissa maksettuja palkkoja, toisaalta muiden läänien maataloustyöväen palkkatasoa. Tosin elinkustannuksetkin saattoivat olla Kuopion läänissä alhaisemmat kuin muualla, mutta nimellinen palkkahan on ainoa mittapuu, jonka avulla muuttajat itse voivat verrata eri paikkakuntien tarjoamia toimeetulomahdollisuuksia keskenään.

Mitä erityisesti tutkimuksemme kohdekuntiin tulee, niistä ei ole mitään erityistä palkkatilastoa olemassa, mutta todennäköisesti maataloustyöväen palkkataso on niissä ollut suurin piirtein sama kuin Kuopion läänissä keskimäärin. Samat ovat myös olleet sen vaikutukset: ensinnä vilkas muuttoliike teollisuuteen ym. elinkeinoihin sekä muiden, etenkin eteläisten läänien maatalousalueille, sitten siitä johtuva maataloustyöväen palkkojen nousu. Aineistomme kerääjien antamien tietojen mukaan näyttää siltä, kuin näissä kunnissa palkkojen nousu olisi kesällä 1945 ehtinyt jo pitemmälle kuin Kuopion läänissä yleensä. Maataloushallituksen palkkatilaston mukaan esim. talonruokaisten naisten vuosipalkka oli v. 1945 Kuopion läänissä 22.378 mk eli vähän enemmän kuin koko maassa keskimäärin $(22.065$ mk). Nilsiässä kerrotaan karjapalvelijoiden kuitenkin yleensä pyytäneen palkakseen ruoan ja asunnon lisäksi työjalkineet, työtakit ja kilon villoja sekä $3.000 \mathrm{mk}$ rahaa kuukaudessa. Ja kun miehen palkkapäivätyöstä talon ruoassa maksettiin kesällä 1945 tilaston mukaan Kuopion läänissä mk 176: 53 ja koko maassa keskimäärin mk $172: 76^{25}$, vastaava palkka Nilsiässä oli 250 mk. Tästä huolimatta Nilsiässä oli vaikea saada työvoimaa maatalouteen, kun esim. mies samaan aikaan saattoi ansaita metsätöissä keskinkertaisella työntahdilla $700-800 \mathrm{mk}$ ja hevosmies 1.600 mk päivässä. 
M a a talouden ty öaika. Vielä vuosisatamme alussa työpäivä oli maataloudessakin varsin pitkä, keskimäärin noin 14 tuntia. Olosuhteiden pakosta ja etenkin teollisuuden työajan säännöstelemisestä johtuen maataloudenkin työpäivä on vuosikymmenien kuluessa lyhentynyt ollen silti edelleenkin pitempi sitä 8 tunnin työpäivää, joka jo kolmisenkymmentä vuotta on ollut käytännössä teollisuudessa ja monilla muilla aloilla ${ }^{26}$. Maan eri osissa on tässä suhteessa todettavissa melkoista eroavǎisuutta, kuten ilmenee esim. v. 1937 asetetun ns, maataloustyöväkikomitean tutkimuksista.

Komitean keräämä aineisto osoitti, että maatalouden bruttotyöpäivä, so. työn alkamisen ja päättymisen välinen aika, oli vv. 1936-1937 keskimäärin 10,5 tuntia ja aterialomat vähentämällä saatu nettotyöpäivä vähän yli 9 tuntia. Työpäivän keskimääräinen pituus oli kuitenkin Itä- ja Pohjois-Suomessa huomattavasti suurempi kuin Etelä- ja Länsi-Suomessa, mihin osaltaan vaikutti se, että tutkimuksessa oli otettu huomioon myös puhdetyöt, joita Etelä- ja Länsi-Suomessa ei enää sanottavammin tehdä. Kuopion läänissä bruttotyöpäivä oli noin $11-12$ tuntia ja nettotyöpäivä noin 9,3 tuntia, joten työaika oli siellä sekä kesällä että talvella pitempi kuin missään muussa läänissämme Oulun lääniä lukuun ottamatta ${ }^{27}$.

Edellä mainitut luvut ilmoittavat työajan varsinaisissa peltoviljelystöissä. Karjataloudessa bruttotyöpäivä oli paljon pitempi: sisäruokintakautena keskimäärin 13,89 tuntia ja laidunkautena 13,96 tuntia koko maassa, ja Kuopion läänissä vastaavasti 14,06 ja 13,70 tuntia. Karjataloustyöväen nettotyöpäivää on vaikea määritellä, sillä etenkin pienillä ja keskikokoisilla viljelmillä karjanhoitajat osallistuvat niinä päivän aikoina, jolloin karja ei vaadi heidän huolenpitoaan, viljelmän muihin töihin. Naispuolisen työväen ruokailuväliajatkin supistuvat usein hyvin lyhyiksi, sillä kun miehet aterian jälkeen asettuvat ruokalevolle, naisten on sillä välin pestävä astiat ja huolehdittava karjasta ehtiäkseen sitten taas miesten mukana peltotöihin. Varsinaisen työajan päätyttyäkin heillä vielä on moninaisia kotitaloustöitä 
suoritettavana. Näin ollen karjataloustyöväen nettotyöaika monissa tapauksissa lähentelee bruttotyöaikaa.

Karjataloudessa työpäivä alkaa sisäruokintakaudella yleisesti klo 5, mutta mitä suurempi viljelmä on, sitä aikaisemmin työt on aloitettava, joten klo 3 :nkaan »herätys» ei ole suurviljelmillä harvinainen. Työt jatkuvat sitten noin klo 19:ään asti, mutta esim. Kuopion läänissä ne mainitun komitean saamien tietojen mukaan monissa tapauksissa päättyivät vasta klo 20 tai $20,30=$.

Naisten työpäivä alkaa maataloudessa siis vähintään kaksi tuntia aikaisemmin kuin teollisuudessa eli sellaisena aikana vuorokaudesta, jolloin varsinkin nuori ihminen nukkuu sikeimmin ja jolloin vuoteesta nouseminen tuntuu hänestä vaikeimmalta. Iltaisin työt jatkuvat paljon kauemmin kuin ns. kaupunkilaiselinkeinoissa, ja niiden päättymisen ajankohta voi jäädä epàmääräiseksi. Esim. eläimille sattuvat onnettomuudet, sairaudet, poikimiset ym. voivat odottamatta aiheuttaa ylimääräistä työtä.

Tavallista pitemmäksi työaika muodostuu pienviljelijöiden ja heidän vaimojensa osalta. Ellei varoja työväen palkkaamiseen ole eikä lapsistakaan ehkä ole vielä tai enää apua, viljelijäpariskunnan on suoritettava itse kaikki ne moninaiset työt, joita maanviljelyksen sekä karja- ja kotitalouden piirissä päivittäin esiintyy. Näissä olosuhteissa voi etenkin perheen äidin työtaakka muodostua hänelle aivan ylivoimaiseksi. Maalaisemännän ajankäyttöä koskevassa tutkimuksessaan tohtori Elli Saurio on saanut 40 maanviljelijäemännän keskimääräiseksi päivittäiseksi työajaksi vuoden mittaan 12,7 tuntia, mutta se vaihteli jonkin verran vuoden eri aikoina ollen pisimmillään heinäsyyskuussa $(13,1 \text { tuntia })^{29}$. Tohtori Nils Westermarck on omassa kysymystä selvittelevässä tutkimuksessaan päätynyt jotenkir samaan tulokseen saaden perheenemäntien työpäivän keskimääräiseksi pituudeksi 13,11 tuntia. Yksityisissä tapauksissa esiintyy tietenkin melkoista vaihtelua niin suuntaan kuin toiseenkin. Pisin tohtori Westermarckin aineistossa esiintyva keskimääräinen työpäivä on 16,30 tuntia $^{30}$.

Tutkimuksemme kohdekunnissa työaika ei ole ollut sen lyhyempi kuin muuallakaan Kuopion läänissä, pikemmin päin- 
vastoin. Niinpä Tuusniemellä työolot ovat - aineistomme kerääjän kertoman mukaan - aina olleet järjestelemättömiä ja työpäivät hyvin pitkiä. Muuruvedeltä taas ilmoitetaan, että työaika on siellä ollut naisilla yleensä 14 tuntia ja miehilläkin 12-13 tuntia päivittäin. Erityisesti korostetaan pienviljelijäin emäntien vaikeata asemaa. Kun ottaa huomioon sen ratkaisevan merkityksen, mikä heillä on niin hyvin koti- ja karjatalouden kuin pelto- ym. töiden säännölliselle kululle, on ymmärrettävää, että he viimeiseen asti koettavat huolehtia tehtävistään, myös sairauden ja raskauden aikana. Niinpä Muuruvedellä eräs äiti kertoi nousseensa jo heti synnytyksen jälkeisenä päivänä valmistamaan rúokaa perheelleen. Tavallisempaa kuitenkin on, että lapsivuoteesta nouseminen tapahtuu »vasta» parin päivän kuluttua.

Kun olosuhteet ovat tällaiset, ei ole ihmeteltävä sitä, että maaseudun nuoret naiset ovat haluttomia jäämään karjapalvelijoiksi taikka pienviljelijöiden emänniksi maaseudulle, kun he asutuskeskuksissa voivat päästä paljon helpommille päiville.

Työolosuhteet maataloudessa. Maataloustyöllä on asutuskeskuksissa tarjona oleviin töihin verrattuna eräitä huomattavia etuja. Työ tapahtuu raittiissa ilmassa ja usein hyvinkin kauniissa ympäristössä, se on vaihtelevampaa, hauskempaa ja vähemmän kuumeista kuin esim. teollisuustyö. Mutta sillä on varjopuolensakin. Maamies saa ihanien säiden ohella kokea myös hellettä ja pakkasta, tuulta ja sadetta. Työ on voimia kysyvää ja usein epäsiistiä. Karjataloustyöt on suoritettava ehkä hyvinkin puutteellisissa olosuhteissa. Niinpä esim. Muuruvedellä, vaikka se tutkimuksemme kohdekunnista näyttääkin olevan maataloudellisesti edistynein, karjansuojien mainitaan suurissakin taloissa olevan melko vaatimattomia ja pienimmissä hyvin vajavaisia. Pienviljelmien navetoissa ovat ahtaus, kylmyys ja likaisuus monesti niin luonnollisina pidettyjä ilmiöitä, ettei näiden vikojen korjaamista edes tulla ajatelleeksi. Ja vesi on kannettava navettoihin samoin kuin asuinrakennukseenkin ehkä pitkienkin matkojen takaa. 
Kaiken tämän rinnalla ne valoisat ja siistit tehdassalit sekä muut työpaikat, joista asutuskeskuksiin siirtyneet tuttavat ovat tienneet kertoa, vaikuttavat hyvin houkuttelevilta. Mahdollista on, että esim. kaupunkiin muuttaja todellisuudessa joutuu tekemään raskaita päiviä uutisrakennuksilla taikka satamassa ta1 noen ja rasvan tahraamana ahertamaan jossakin verstaassa, mutta silti hän mahdollisesti lohduttelee itseään sillä, että työ joka tapauksessa on arvokkaampaa kuin aherrus maalla lehmien ja lannan parissa. »Ei työ miestä pahenna», toteaa vanha sananlasku, mutta monien kohdalta on luottamus tähän samoin kuin muihinkin vanhoihin totuuksiin alkanut pahasti järkkyä.

Yhteiskuntaluokkien väliset suhteet. Huomattava eroavaisuus on olemassa myös toisaalta kaupunkilaisen tai ns. kaupunkilaiselinkeinon palveluksessa olevan työläisen ja toisaalta maataloustyöläisen asemassa ja koko elämässä myöskin vapaa-aikoina. Maatyöläinen pysyy »työläisenä» vielä työnsä päätettyäänkin. Menipä hän vapaa-aikanaan mihin kotiseutunsa seuraan, kauppaan tai kahvilaan tahansa, kaikki tietävät, että hän »renkinä» tai »piikana» siinä ja siinä talossa. Maaseudulla eri yhteiskuntaluokkien väliset rajat ovat vielä paljon selvemmät ja vaikeammin ylitettävät kuin kaupungeissa. Maalla ihmisen arvo ja hänen osakseen saama kohtelu näyttää vielä enemmän kuin asutuskeskuksissa riippuvan hänen sosiaalisesta asemastaan ja vähemmän hänen henkilökohtaisista ominaisuuksistaan. Jos joku tarmonsa tai muiden edullisten ominaisuuksiensa avulla on päässyt kohoamaan luokasta toiseen, häntä katsellaan maaseudulla jossakin määrin toisin tuntein kuin kaupungissa.

Aivan toinen on työläisen asema asutuskeskuksissa. Palattuaan työstä ja muutettuaan vaatteensa hän on kuin toinen ihminen. Mennessään johonkin myymälään, ravintolaan tms., - hän ilman muuta edellyttää, että häntä kohdellaan samalla tavalla kuin toisiakin. Keskiajalla, maaorjuuden aikautena, oli tapana sanoa: »Kaupungin ilma tekee vapaaksi». Sama pitää paikkansa vielä nykyäänkin, joskin hiukan toisessa merkityksessä. 
Muita maaltamuuttoa edistäviä tekijöitä. Edellä kuvattujen seikkojen ohella maalta ja maataloudesta muuttoon vaikuttavat monet muutkin tekijät, joilla kuitenkin yleensä on vain toisarvoinen merkitys. Tässä ei ole mahdollista puuttua niihin tarkemmin, joten on tyydyttävä vain eräisiin viitteisiin.

»Maaltapaosta» puhuttaessa mainitaan tavallisesti eräänä siihen vaikuttavana seikkana maaseudun puutteelliset asuntoolot. Niissä onkin kieltämättä paljon korjaamisen varaa, mutta tuntuu kuitenkin siltä, kuin niiden merkitystä olisi yliarvioitu. Harvat ovat varmaan ne henkilöt, jotka yksistään asunto-olojensa puutteellisuuden vuoksi jättävät maaseudun. Tähän viittaa myöskin se, että vaikka asuntopula on kaupungeissa äsken päättyneen sodan aikana ja sen jälkeen ollut ennen näkemättömän ankara, se ei ole estänyt maaseutulaisia siirtymästä niihin, vaan viranomaisten on pitänyt ryhtyä tämän muuttovirran hillitsemiseksi erikoistoimenpiteisiin.

Paljon on myös puhuttu maaseudulla vallitsevasta opiskelumahdollisuuksien ja huvitilaisuuksien puutteesta ja sen koko henkisen elämän takapajuisuudesta. Kirjastoja on perin vähän, opintokerho- ja seuratoiminta kituu kykenevien johtajavoimien puutteessa, ne verraten vähälukuiset seurojentalot ja urheilukentät, joita on olemassa, ovat rappiotilassa jne. Kaikki nämä puutteellisuudet vähentävät tietenkin suuresti maalaiselämän viihtyisyyttä ja jarruttavat maalaisnuorison pyrkimyksiä kehittää itseään. Mutta ainakin yhtä paljon kuin ne ovat »maaltapaon» syynä, ne ovat sen seurausta. Kun maaseutu jatkuvasti vuodesta toiseen menettää suuren osan yritteliäintä ja toimeliainta väestöään, sen henkinen elämä joutuu siitä talouselämän tavoin auttamattomasti kärsimään.

Enemmän kuin äskenmainitut seikat vaikuttavat maalta muuttoon psykologiset tekijät. Seikkailunhalu näyttelee siinä tiettyä osaa, tuskinpa sentään niin suurta kuin nuorten salainen, ehkei täysin tietoiseksikaan tullut toive siitä, että suuremmalta paikkakunnalta voisi helpommin kuin kotiseudulta löytää itselleen sopivan elämänkumppanin. Ja erikoisesti on syytä koros- 
taa sitä tenhoavaa vaikutusta, mikä suurella kaugungilla ja sen vilkkaalla elämänrytmillä on nuoriin mieliin. Meillä Suomessa etenkin Helsinki on sellainen skultainen kaupunki», jonne monen nuoren miehen ja naisen mieli palaa kaukaisilla syrjäseuduillakin.

Mutta mitä erityisesti tutkimuksemme kohdekuntiin tulee, tärkeimpänä poismuuton syynä niissä ovat kuitenkin olleet taloudelliset. ja sosiaaliset tekijät. Joskin muutkin näkökohdat on otettu ratkaisussa huomioon, pääpyrkimyksenä muuttajilla silti on ollut taloudellisen ja yhteiskunnallisen asemansa parantaminen.

\section{Lähdeviitteitä.}

1 Granö, J. G., Suomen maantieteelliset alueet, Porvoo 1932, s. 81.

2 Suomenmaa, Maantieteellis-taloudellinen ja historiallinen tietokirja, VIII osa: Kuopion lääni, Porvoo 1927, ss. 117-121, 162-166, 175-181 ja $188-191$.

3 Suomen virallinen tilasto (SVT) VI, 98: 1, s. 16.

4 SVT VI, 56, 76 ja 98 sekä väestösuhteita ja väestönmuutoksia koskevat julkaisusarjat.

5 SVT VI, väestönmuutostilasto vuosilta 1921-1944. Aluejärjestelyjen yhteydessä seurakunnasta toiseen siirretyt on jätetty huomioon ottamatta.

6 Vrt. esim. Ravenstein, E. G., The Laws of Migration, Journal of the Royal Statistical Society, June 1885, s. 199 ja Thomas, D. S., Social and Economic Aspects of Swedish Population Movements 1750-1933, New York 1941, s. 297.

7 Vrt. esim. Kaila, T. T., Europan Venäjän väestönsiirroista XIX. vuosisadan lopulla, Helsinki 1914, s. 103 ja Rauchberg, H., Wanderungen in Oesterreich, Allgem. Stat. Archiv III, Tübingen 1894, s. 197.

8 Vrt. SVT VI, $56: 3$, s. 34 .

- Tiedot perustuvat Tilastollisessa päätoimistossa oleviin kymmenvuotistilaston alkuperäistauluihin.

10 SVT VI, $76: 3$, ss. 7 ja 9.

11 SVT XVIII A 56, ss. 14-16.

12 Vrt. Wichman, A., Metsä- ja uittotyöläiset sekä heidän työansionsa, Suomen Uittajainyhdistys r.y:n vuosikirja VIII, Helsinki 1939, s. 78.

${ }_{13}$ Suomenmaa, VIII osa, ss. 118-119 ja 180.

14 Laitakari, A., Uutta kaivosrintamalta, Uusi Suomi 23/11 1946.

15 Suhdelukujen pohjana olleet peltoalat on saatu maataloushallituksen tilastotoimiston v. 1943 suorittamista tarkistuslaskelmista, jotka antavat peltoalasta luotettavammat tiedot kuin vuoden 1941 yleinen maatalouslaskenta. Kuntien koko maa-ala on mainittu SVT:ssa VI, 98:1, s. 16.

16 Cajander, E., Asutustilallisten toimeentulomahdollisuuksista Suomessa, Helsinki 1923, s. 76. - Asutustoimintakomitean mietintö, Komiteanmietintö 1933: 11, Helsinki 1933, ss. $167-169$ ja 174. 
17 SVT III, 38: 3 , ss. $47-48$.

18 Yleistä maatalouslaskentaa koskevat maataloushallituksen tilastotoimiston työtaulut vuosilta 1929 ja 1941 sekä SVT III, 17, ss. 14-15.

19 von der Goltz, Theodor, Die ländliche Arbeiterklasse und der Preussische Staat, Jena 1893, ss. 142-145. - Sering, Max, Die innere Kolonisation im östlichen Deutschland, Schriften des Vereins für Sozialpolitik LVI, Leipzig 1893, ss. 9-14. - Myrdal, G., Industrialization and Population, Economic Essays in Honour of Gustav Cassel, London 1933, ss. $449-450$.

zo SVT III, 38: 2, ss. $14-16$.

21 Vrt. Komiteamietintö 1933: 11, s. 160.

22 Palkkaneuvoston asettaman toimikunnan mietintö maataloustyöväen palkkojen järjestelystä, Komiteamietintö 1943: 1, ss. 11-13.

23 Waris, Klaus, Kuluttajain tulot, kulutus ja säästäminen suhdannekehityksen valossa Suomessa vuosina 1926-1938, Helsinki 1945, ss. $73-74$.

24 Komiteamietintö 1943: 1, ss. 21-24.

2s Maataloushallituksen tilastotoimistosta saatujen ennakkotietojen mukaan. Sosiaalisen tutkimustoimiston palkkatilaston mukaan ko. päiväpalkat olivat vielä alhaisemmat, nim. Kuopion läänissä mk 157: 99 ja koko maassa keskimäärin mk 153: 73 (Sosiaalinen Aikakauskirja 1945, s. 425).

26 Komiteamietintö $1943: 1$, s. 5 .

27 Lehtinen, Artturi, Maatalouden työaika, Sosiaal, Aikak. 1939, ss. 412 $-413$.

28 Lehtinen, Artturi, Karjatalouden työaika, Sosiaal. Aikak. 1939, ss. 604 605.

29 Saurio, Elli, Maalaisemännän ajankäyttö, Helsinki 1947, s. 73.

30 Westermarck, Nils, Tutkimuksia kodin piirissä työskentelevien naisten työpäivän pituudesta, Työtehoseuran julkaisuja n:o 8, Kerava 1946, ss. 14-16. 